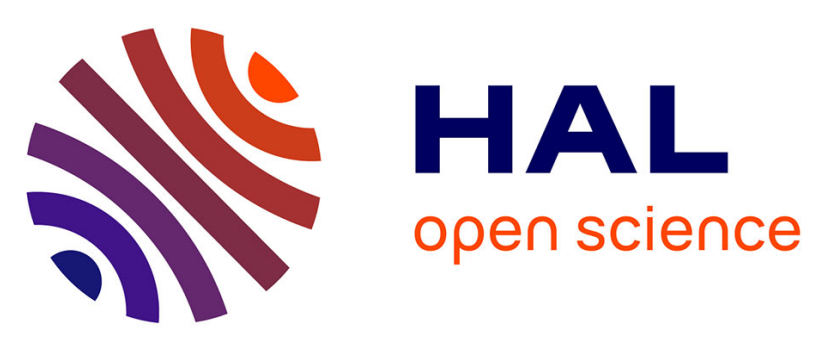

\title{
Four-Legged Piano Stool Molybdenum(II) Compounds without Carbonyl Ligands. 4. Cyclopentadienylmolybdenum(II) Complexes with 16-Electron and 18-Electron Configurations
}

Fatima Abugideiri, James C Fettinger, D. Webster Webster Keogh, Rinaldo Poli

\section{To cite this version:}

Fatima Abugideiri, James C Fettinger, D. Webster Webster Keogh, Rinaldo Poli. Four-Legged Piano Stool Molybdenum(II) Compounds without Carbonyl Ligands. 4. Cyclopentadienylmolybdenum(II) Complexes with 16-Electron and 18-Electron Configurations. Organometallics, 1996, 15 (21), pp.44074416. 10.1021/om960331d. hal-03375401

\author{
HAL Id: hal-03375401 \\ https://hal.science/hal-03375401
}

Submitted on 12 Oct 2021

HAL is a multi-disciplinary open access archive for the deposit and dissemination of scientific research documents, whether they are published or not. The documents may come from teaching and research institutions in France or abroad, or from public or private research centers.
L'archive ouverte pluridisciplinaire HAL, est destinée au dépôt et à la diffusion de documents scientifiques de niveau recherche, publiés ou non, émanant des établissements d'enseignement et de recherche français ou étrangers, des laboratoires publics ou privés. 


\title{
Four-Legged Piano Stool Molybdenum(II) Compounds without Carbonyl Ligands. 4. Cyclopentadienylmolybdenum(II) Complexes with 16-E lectron and 18-Electron Configurations
}

\author{
Fatima Abugideiri, J ames C. Fettinger, D. Webster Keogh, and Rinaldo Poli* \\ Department of Chemistry and Biochemistry, University of Maryland, \\ College Park, Maryland 20742
}

Received May 3, 1996

\begin{abstract}
Monocyclopentadienyl complexes of $\mathrm{Mo}(\mathrm{II})$ with 16- and 18-electron configurations of the form (Ring) $\mathrm{MoClL}_{x}\left(\mathrm{x}=2\right.$, Ring $=\mathrm{Cp}, \mathrm{L}=\mathrm{PMe}_{2} \mathrm{Ph} ; \mathrm{x}=2$, Ring $=\mathrm{Cp} *, \mathrm{~L}=\mathrm{PMe}_{3}, \mathrm{PMe}_{2} \mathrm{Ph}$, $\mathrm{L}_{2}=$ dppe; $\mathrm{x}=3$, Ring $=\mathrm{Cp}, \mathrm{L}=\mathrm{PM} \mathrm{e}_{2} \mathrm{Ph}$ ) are described. All of the 16-electron complexes are paramagnetic with an $\mathrm{S}=1$ ground state, as shown by magnetic measurements in the solid state and in solution, and by the contact-shifted ${ }^{1} \mathrm{H}$ NMR spectra. The structure of $\mathrm{Cp} * \mathrm{MoCl}$ (dppe) was determined by X-ray diffraction methods. The 18-electron complex $\mathrm{CpMoCl}\left(\mathrm{PMe}_{2} \mathrm{Ph}\right)_{3}$ has been synthesized by reduction of $\left\{\mathrm{CpMoCl}_{2}\right\}_{n}$ with $\mathrm{Na}$ in the presence of 3 equiv of phosphine. It has been fully characterized by ${ }^{1} \mathrm{H}$ and ${ }^{31} \mathrm{P} N M R$, chemical analysis, and X-ray structural determination. Thermolysis of a THF or $\mathrm{C}_{6} \mathrm{D}_{6}$ solution of this 18-electron species generates the 16-electron paramagnetic $\mathrm{Mo}(\mathrm{II})$ complex $\mathrm{CpMoCl}$ $\left(\mathrm{PMe}_{2} \mathrm{Ph}\right)_{2}$. The $\mathrm{Cp} * \mathrm{MoCl}_{2}\left(\mathrm{~L}=\mathrm{PMe}_{3}\right.$ and $\left.\mathrm{PMe}_{2} \mathrm{Ph}\right)$ systems react with 2-electron-donor ligands, i.e. $\mathrm{CO}$ and $\mathrm{H}_{2}$, to afford stable 18-electron complexes. The carbonyl derivative $\mathrm{Cp} * \mathrm{MoCl}(\mathrm{CO})\left(\mathrm{PMe}_{2} \mathrm{Ph}\right)_{2}$ has also been characterized by $\mathrm{X}$-ray crystallography.
\end{abstract}

\section{Introduction}

We are interested in the effect of the spin state on the energetic stabilization of electronically unsaturated organometallic complexes. For instance, a 16-electron complex might have the 2 electrons of highest energy unpaired and located 1 each in the two highest energy orbitals of the valence shell, giving rise to a spin triplet, or they may be paired in the same orbital, leaving a relatively accessible LUMO:

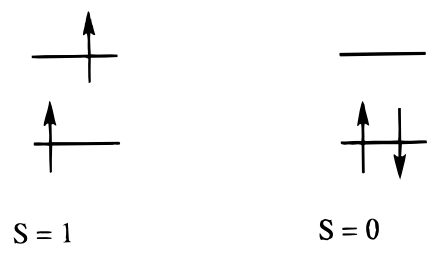

A similar situation may be pictured for 15-electron complexes, where the choice is between an $\mathrm{S}=1 / 2$ and an $\mathrm{S}=3 / 2$ configuration.

The electronic configuration has profound effects on the reactivity of the molecule; for instance, an $\mathrm{S}=0$ 16-electron complex has the ability to undergo rapid ligand additions or oxidative-addition reactions, whereas the same reactions on the spin triplet counterpart should be slower because they involve a forbidden (in principle) ${ }^{1}$ crossover to the singlet state of the 18electron product. The energetics of stable molecules and reaction intermediates (and therefore the reaction thermodynamics, kinetics, and mechanism) can also be affected by spin changes. ${ }^{2}$ We therefore wish to study

${ }^{\otimes}$ Abstract published in AdvanceACS Abstracts, September 1, 1996. (1) Detrich, J . L.; Reinaud, O. M.; Rheingold, A. L.; Theopold, K. H. J . Am. Chem. Soc. 1995, 117, 11745-11748.

(2) Poli, R. Comments I norg. Chem. 1992, 12, 285-314. phenomenologically the factors that determine the choice of spin state.

In simple terms, the choice between the above two electronic configurations is determined by the relative magnitude of the separation between the two orbitals and the pairing energy. Given a certain energetic separation between the two orbitals in question, the low effective positive charge on the metal center in typical low-oxidation-state organometallic compounds results in diffuse metal orbitals and therefore low pairing energies, favoring the low-spin configuration. Lowoxidation-state 16-electron complexes are typically reactive intermediates which easily engage in ligandaddition or oxidative-addition reactions. In most instances, the assumption is implicitly made in the literature that such intermediates have a low-spin configuration, or the question of their spin state is simply not addressed. There are, however, important cases of high-spin intermediates, for instance $\mathrm{Fe}(\mathrm{CO})_{4}$ and $\mathrm{CpCo}(\mathrm{CO}){ }^{3-5}$

For higher oxidation state complexes, the higher effective positive charge on the metal center is expected to result in a greater pairing energy and a higher relative stability of the high-spin configuration with respect to the alternative low-spin one. A good example is provided by the isostructural and isoelectronic series of four-legged piano stool, $\mathrm{d}^{2}$ (16-electron) compounds of $\mathrm{Zr}(\mathrm{II}),\left(\eta^{6}-\mathrm{C}_{6} \mathrm{H}_{5} \mathrm{Me}^{2} \mathrm{ZrCl}_{2}\left(\mathrm{PMe}_{3}\right)_{2}{ }^{6}\right.$ (diamagnetic), $\mathrm{Nb}(\mathrm{III}), \mathrm{Cp}^{*} \mathrm{NbCl}_{2}\left(\mathrm{PMe}_{3}\right)_{2}{ }^{7}$ (paramagnetic), and $\mathrm{Mo}(\mathrm{IV})$,

(3) Poliakoff, M.; Weitz, E. Acc. Chem. Res. 1987, 20, 408-414.

(4) Bengali, A. A.; Bergman, R. G.; Moore, C. B. J . Am. Chem. Soc 1995, 117, 3879-3880.

(5) Siegbahn, P. E. M. J . Am. Chem. Soc. 1996, 118, 1487-1496.

(6) Diamond, G. M.; Green, M. L. H.; Walker, N. M.; Howard, J . A K.; Mason, S. A. J . Chem. Soc., Dalton Trans. 1992, 2641-2647.

(7) Siemeling, U.; Gibson, V. C. J . Organomet. Chem 1992, 424 159-161. 
$\left[\mathrm{CpMoCl}{ }_{2}\left(\mathrm{PMe}_{3}\right)_{2}\right]^{+}$(paramagnetic). ${ }^{8}$ Since pairing energies are lower for more diffuse orbitals, a higher spin state is more likely observed for an unsaturated complex of a $3 \mathrm{~d}$ metal versus the $4 \mathrm{~d}$ and $5 \mathrm{~g}$ congeners. The isoelectronic intermediates $\mathrm{CpM}(\mathrm{CO})(\mathrm{M}=\mathrm{Co}, \mathrm{Rh})$ illustrate the dramatic difference in chemical reactivity for species with different spin: while the $\mathrm{S}=0 \mathrm{CpRh}$ (CO) rapidly binds 2-electron-donor ligands (even the inert gases $\mathrm{Kr}$ and $\mathrm{Xe}$ !) and oxidatively add $\mathrm{C}-\mathrm{H}$ bonds of saturated hydrocarbons, $, 9,10$ the corresponding $S=1$ $\mathrm{CpCo}(\mathrm{CO})$ fragment does not engage in either process. ${ }^{4}$ We have shown that the phosphine ligand exchange on the 17-electron $(S=1 / 2) \mathrm{CpMoX}_{2} \mathrm{~L}_{2}$ complexes ( $\mathrm{X}=$ halogen; $\mathrm{L}=$ tertiary phosphine) occurs via the 15electron intermediate $\mathrm{CpMoX}_{2} \mathrm{~L}$ (rather than through the associative mechanism which is typical of lowoxidation-state radicals) and advanced the hypothesis that a spin state change to a more favorable $S=3 / 2$ configuration is at least in part responsible for this change of mechanism. ${ }^{11}$ We shall address elsewhere how pairing energies affect the relative stabilities of 15electron spin quartet $\mathrm{CpMCl}_{2}\left(\mathrm{PH}_{3}\right)$ versus 17-electron spin doublet $\mathrm{CpMCl}_{2}\left(\mathrm{PH}_{3}\right)_{2}$ for $\mathrm{M}=\mathrm{Cr}$, Mo. ${ }^{12}$

We have now embarked on a synthetic project designed to probe the stability and spin state of electronically unsaturated organometallic complexes in different oxidation states. We have found that for the Mo(IV) $\left(\eta-\mathrm{C}_{5} \mathrm{R}_{5}\right) \mathrm{MoCl}_{3} \mathrm{~L}_{n}$ system, when the less sterically encumbered $\mathrm{Cp}$ and $\mathrm{L}=\mathrm{PMe}_{3}, \mathrm{PMe}_{2} \mathrm{Ph}$ ligands are employed, an equilibrium is established between the 18electron $\mathrm{CpMoCl}_{3} \mathrm{~L}_{2}$ and the 16-electron spin triplet $\mathrm{CpMoCl}_{3} \mathrm{~L}$ complexes, whereas only the 16-electron mono(phosphine) adduct could be obtained for the sterically more encumbered $\mathrm{Cp}^{*}$ systems and also for the $\mathrm{Cp}$ system with the bulkier phosphine $\mathrm{PMePh}_{2}{ }^{13}$ Also, the stable 16-electron [CpMoCl $\left.2\left(\mathrm{PMe}_{3}\right)_{2}\right]^{+}$complex reacts promptly and quantitatively with $\mathrm{Cl}^{-}$to afford $\mathrm{CpMoCl}_{3}\left(\mathrm{PMe}_{3}\right)_{2}$ (in equilibrium with $\mathrm{CpMoCl}\left(\mathrm{PMe}_{3}\right)$ ), whereas $\left[\mathrm{CpMol}_{2}\left(\mathrm{PMe}_{3}\right)_{2}\right]^{+}$and $\mathrm{I}^{-}$do not show any tendency to form the corresponding 18-electron adduct.14,15 All these 16-electron four-legged piano stool $\mathrm{Mo}(\mathrm{IV})$ complexes have a spin triplet ground state.

For the Mo(III) $\left(\eta-\mathrm{C}_{5} \mathrm{R}_{5}\right) \mathrm{MoCl}_{2} \mathrm{~L}_{n}$ system, we have not yet been able to produce a stable 15-electron monophosphine adduct, whereas a number of 17-electron bisadducts have been obtained, isolated, and characterized. ${ }^{16}$ We have shown that this is not due to insufficient stabilization of the alleged $\left(\eta-\mathrm{C}_{5} \mathrm{R}_{5}\right) \mathrm{MoCl}{ }_{2} \mathrm{~L}$ complex by the expected $\mathrm{S}=3 / 2$ el ectronic configuration with respect to the bis(phosphine) adduct but rather to a ligand disproportionation reaction to ultimately afford the

(8) Krueger, S. T.; Poli, R.; Rheingold, A. L.; Staley, D. L. Inorg. Chem. 1989, 28, 4599-4607.

(9) Schultz, R. H.; Bengali, A. A.; Tauber, M. J .; Weiller, B. H.; Wasserman, E. P.; Kyle, K. R.; Moore, C. B.; Bergman, R. G. J . Am. Chem. Soc. 1994, 116, 7369-7377.

(10) Bengali, A. A.; Schultz, R. H.; Moore, C. B.; Bergman, R. G. J Am. Chem. Soc. 1994, 116, 9585-9589.

(11) Cole, A. A.; Fettinger, J . C.; Keogh, D. W.; Poli, R. Inorg. Chim. Acta 1995, 240, 355-366.

(12) Cacelli, l.; Poli, R.; Rizzo, A. To be submitted for publication. (13) Abugideiri, F.; Gordon, J. C.; Poli, R.; Owens-Waltermire, B. E.; Rheingold, A. L. Organometallics 1993, 12, 1575-1582.

(14) Poli, R.; Owens, B. E.; Linck, R. G. J . Am. Chem. Soc. 1992, 114, 1302-1307.

(15) Poli, R.; Rheingold, A. L.; Owens-Waltermire, B. E. Inorg. Chim. Acta 1993, 203, 223-227.

(16) Poli, R. J . Coord. Chem. B 1993, 29, 121-173. thermodynamically more favorable combination of $(\eta$ $\left.\mathrm{C}_{5} \mathrm{R}_{5}\right) \mathrm{MoCl}_{2} \mathrm{~L}_{2}$ and $\left[\left(\eta-\mathrm{C}_{5} \mathrm{R}_{5}\right) \mathrm{MoCl}_{2}\right]_{2} \cdot{ }^{17}$

Here we report the results of our investigations on the class of $\mathrm{Mo}(\mathrm{II})$ complexes of general formula $(\eta-$ $\left.\mathrm{C}_{5} \mathrm{R}_{5}\right) \mathrm{MoClL}_{n}$, for which either an 18-electron $(\mathrm{n}=3)$ or a 16-electron $(n=2)$ configuration is expected. The lowering of the metal oxidation state from Mo(IV) to $\mathrm{Mo}(\mathrm{III})$ to $\mathrm{Mo}(\mathrm{II})$ is of interest because (i) the preference for a high-spin electronically unsaturated configuration should decrease and (ii) lower coordination numbers are sufficient to achieve electronic saturation; therefore, electronically unsaturated complexes can be assumed to be less dependent on steric effects (e.g. compare the three-legged piano stool $\mathrm{CpMoClL}_{2}$ with the four-legged piano stool $\mathrm{CpMoCl}_{3} \mathrm{~L}$, both having a 16-electron count). Our studies demonstrate that 16-electron Mo(II) complexes (i) unlike the 15-electron $\mathrm{Mo}(\mathrm{III}) \mathrm{CpMoX}_{2} \mathrm{~L}$ compl exes ${ }^{17}$ are stable in solution and (ii) like the 16electron $\mathrm{Mo}$ (IV) $\mathrm{CpM} \mathrm{oCl}_{3} \mathrm{~L}$ systems preferably adopt a high-spin configuration. Part of this work has been previously communicated. ${ }^{18}$

\section{Experimental Section}

General Data. All operations were carried out under an atmosphere of argon. Solvents were dehydrated by conventional methods and distilled directly from the dehydrating agent prior to use ( $\mathrm{THF}$ and $\mathrm{Et}_{2} \mathrm{O}$ from $\mathrm{Na}$ /benzophenone, heptane and toluene from $\mathrm{Na}$, and $\mathrm{CH}_{2} \mathrm{Cl}_{2}$ from $\mathrm{P}_{2} \mathrm{O}_{5}$ ). NMR spectra were recorded on Bruker WP200 and AF200 spectrometers; the peak positions are reported with positive shifts downfield of TMS as calculated from the residual solvent peaks $\left({ }^{1} \mathrm{H}\right)$ or downfield of external $85 \% \mathrm{H}_{3} \mathrm{PO}_{4}\left({ }^{31} \mathrm{P}\right)$. For each ${ }^{31} \mathrm{P}$ NMR spectrum, a sealed capillary containing $\mathrm{H}_{3} \mathrm{PO}_{4}$ was immersed in the same NMR solvent used for the measurement and this was used as the external reference. EPR spectra were recorded on a Bruker ER200 spectrometer equipped with an X-band microwave generator. Cyclic voltammograms were recorded with an EG\&G 362 potentiostat connected to a Macintosh computer through MacL ab hardware/software; the electrochemical cell was a locally modified Schlenk tube with a Pt counter electrode sealed through uranium glass/Pyrex glass seals. The cell was fitted with a $\mathrm{Ag} / \mathrm{AgCl}$ reference electrode and a Pt working electrode. All potentials are reported vs the $C p_{2} \mathrm{Fe} / \mathrm{Cp}_{2} \mathrm{Fe}^{+}$couple, which was introduced into the cell at the end of each measurement. The solid-state magnetic susceptibility measurements were performed with a J ohnson Matthey magnetic susceptibility balance. The elemental analyses were by M-H-W Laboratories, Phoenix, AZ or Galbraith Laboratories, Inc., Knoxville, TN. Cp*M $\mathrm{MCl}_{4}, 17,19$ $\mathrm{Cp}^{*} \mathrm{MoCl}_{2}\left(\mathrm{PMe}_{3}\right)_{2},{ }^{20} \mathrm{Cp}^{*} \mathrm{MoCl}\left(\mathrm{PMe}_{3}\right)_{2}\left(\mathrm{~N}_{2}\right),{ }^{20}\left\{\mathrm{CpMoCl}_{2}\right\}_{n},{ }^{21}$ and $\mathrm{Cp} * \mathrm{MoCl}\left(\mathrm{PMe}_{3}\right)_{3}{ }^{22}$ were prepared by literature methods. $\mathrm{PMe}_{3}$ (Aldrich), $\mathrm{PMe}_{2} \mathrm{Ph}$ (Aldrich), dppe (Strem), $\mathrm{H}_{2}$ (Air Products), and $\mathrm{CO}$ (Air Products) were used without further purification.

Preparation of $\mathrm{CpMoCl}\left(\mathrm{PMe}_{2} \mathrm{Ph}\right)_{3}(1)$ and Formation of CpMoCl(PMe $\mathbf{P h})_{2}$ (2). $\left\{\mathrm{CpMoCl}_{2}\right\}_{n}(306 \mathrm{mg}, 1.32 \mathrm{mmol})$ and THF (25 mL) were introduced into a Schlenk tube equipped with a magnetic stirring bar, and $\mathrm{PMe} 2 \mathrm{Ph}(563 \mu \mathrm{L}$, $547 \mathrm{mg}, 3.96 \mathrm{mmol} ; \mathrm{PMe}_{2} \mathrm{Ph} / \mathrm{Mo}$ ratio 3.0) was added to the

(17) Abugideiri, F.; Keogh, D. W.; Kraatz, H.-B.; Poli, R.; Pearson, W. J . Organomet. Chem. 1995, 488, 29-38.

(18) Abugideiri, F.; Keogh, D. W.; Poli, R. J . Chem. Soc., Chem Commun. 1994, 2317-2318.

(19) Murray, R. C.; Blum, L.; Liu, A. H.; Schrock, R. R. Organome tallics 1985, 4, 953-954.

(20) Baker, R. T.; Calabrese, J . C.; Harlow, R. L.; Williams, I. D Organometallics 1993, 12, 830-841.

(21) Linck, R. G.; Owens, B. E.; Poli, R.; Rheingold, A. L. Gazz. Chim. Ital. 1991, 121, 163-168.

(22) Abugideiri, F.; Kelland, M. A.; Poli, R.; Rheingold, A. L. Organometallics 1992, 11, 1303-1311. 
resulting suspension, which was then stirred until the $\mathrm{Cp}$ $\mathrm{MoCl}_{2}$ precipitate reacted with $\mathrm{PMe}_{2} \mathrm{Ph}$ to form $\mathrm{CpMoCl}{ }_{2}\left(\mathrm{PMe}_{2}\right.$ $\mathrm{Ph})_{2}$ (ca. $1 \mathrm{~h}$ ), according to published procedures. ${ }^{23}$ The solution was transferred using a filter cannula into a Schlenk tube containing amalgamated $\mathrm{Na}(30 \mathrm{mg}, 1.32 \mathrm{mmol}$ in $11 \mathrm{~g}$ of $\mathrm{Hg}$ ). The mixture was stirred for 4 days, the color changing from purple-brown to orange-brown, and then filtered through Celite. Thesolvent was removed under reduced pressure, and the residue was extracted with toluene $(200 \mathrm{~mL})$, filtered, and placed in $\mathrm{a}-20{ }^{\circ} \mathrm{C}$ freezer for 10 days. The resulting red crystals were filtered and dried in vacuo. Yield: $218 \mathrm{mg}, 27 \%$. Anal. Calcd for $\mathrm{C}_{29} \mathrm{H}_{38} \mathrm{ClMoP}_{3}$ : C, 57.01; $\mathrm{H}, 6.27$. Found: $\mathrm{C}$, 56.80; $\mathrm{H}$ 6.25. ${ }^{1} \mathrm{H}$ NMR $\left(\mathrm{C}_{6} \mathrm{D}_{6}, \delta\right): 7.6-6.7(\mathrm{~m}, 15 \mathrm{H}, \mathrm{PPh}), 4.59$ (d, $5 \mathrm{H}$, J $\left.\mathrm{H}_{\mathrm{P}}=2 \mathrm{~Hz}, \mathrm{Cp}\right), 1.82\left(\mathrm{vt}, 6 \mathrm{H}\right.$, J $\mathrm{H}-\mathrm{P}=7 \mathrm{~Hz}, \mathrm{P}-\mathrm{CH}_{3}$ ), $1.43\left(v t, 6 \mathrm{H}, \mathrm{J}_{\mathrm{H}-\mathrm{P}}=6 \mathrm{~Hz}, \mathrm{P}-\mathrm{CH}_{3}\right), 0.73\left(\mathrm{~d}, 6 \mathrm{H}, \mathrm{J}_{\mathrm{H}-\mathrm{P}}=3 \mathrm{~Hz}\right.$, $\left.\mathrm{PMe}_{2} \mathrm{Ph}\right)$. ${ }^{31 \mathrm{P} N M R}\left(\mathrm{C}_{6} \mathrm{D}_{6}, \delta\right): 34.7(\mathrm{t}, 1 \mathrm{P}, \mathrm{J} \mathrm{p}-\mathrm{p}=53 \mathrm{~Hz}), 21.9$ $(d, 2 P, J P-P=53 \mathrm{~Hz}$ ). Crystals for the X-ray analysis were obtained by extraction of the crude material into $\mathrm{Et}_{2} \mathrm{O}$ and cooling overnight at $-20^{\circ} \mathrm{C}$.

In a repeat experiment which was run under identical conditions starting from $578 \mathrm{mg}(2.49 \mathrm{mmol})$ of $\left\{\mathrm{CpMoCl}_{2}\right\}_{2}$, $115 \mathrm{mg}(4.98 \mathrm{mmol})$ of $\mathrm{Na}$ amalgamated with $20 \mathrm{~g}$ of $\mathrm{Hg}$, and $1.10 \mathrm{~mL}(7.48 \mathrm{mmol})$ of $\mathrm{PMe} \mathrm{P}_{2} \mathrm{Ph}$ in $90 \mathrm{~mL}$ of $\mathrm{THF}$, the solution obtained after filtration from Celite was evaporated to dryness and the residue was extracted with $\mathrm{n}$-heptane $(70 \mathrm{~mL})$. After filtration, the solution was once more evaporated to dryness and the residue was crystallized from $40 \mathrm{~mL}$ of $\mathrm{Et}_{2} \mathrm{O}$ at -80 ${ }^{\circ} \mathrm{C}$, giving $540 \mathrm{mg}$ of a brown solid. ${ }^{1} \mathrm{H}$ NMR inspection of this solid revealed that it mainly consists of a paramagnetic species, with $\mathrm{CpMoH}\left(\mathrm{PMe}_{2} \mathrm{Ph}\right)_{3}$ impurity (ca. $5 \%$ by NMR integration). ${ }^{1} \mathrm{H} N M R\left(\mathrm{C}_{6} \mathrm{D}_{6}, \delta\right)$ : (a) resonances assigned to $\mathrm{CpMoCl}\left(\mathrm{PMe}_{2}-\right.$ $\mathrm{Ph})_{2}, 21.5\left(\mathrm{br} \mathrm{s}, \mathrm{w}_{1 / 2}=79 \mathrm{~Hz}, 4 \mathrm{H}, \mathrm{o}-\mathrm{Ph}\right), 16.6\left(\mathrm{br} \mathrm{s}, \mathrm{w}_{1 / 2}=80\right.$ $\mathrm{Hz}, 12 \mathrm{H}, \mathrm{PMe}$ ), 10.9 (br s, $\mathrm{w}_{1 / 2}=25 \mathrm{~Hz}, 2 \mathrm{H}, \mathrm{p}-\mathrm{Ph}$ ), 0.85 (br s, $\left.\mathrm{w}_{1 / 2}=42 \mathrm{~Hz}, 4 \mathrm{H}, \mathrm{m}-\mathrm{Ph}\right) ;(\mathrm{b})$ resonances attributed to $\mathrm{CpMoH}\left(\mathrm{PMe}_{2} \mathrm{Ph}\right)_{3}, \mathrm{ca} .7$ (m, Ph), 4.47 (s, 5H, Cp), 1.37 (d, 18H, $\left.\mathrm{Me}, \mathrm{J}_{\mathrm{p}-\mathrm{H}}=2.1 \mathrm{~Hz}\right),-7.7\left(\mathrm{q}, 1 \mathrm{H}, \mathrm{Mo-H}, \mathrm{J}_{\mathrm{H}-\mathrm{P}}=51 \mathrm{~Hz}\right.$ ).

Thermal Treatment of Compound 1. A sample of $\mathbf{1}(20$ $\mathrm{mg}, 0.033 \mathrm{mmol}$ ) was dissolved in $\mathrm{C}_{6} \mathrm{D}_{6}$ (ca. $1 \mathrm{~mL}$ ). The resulting solution was warmed to $45^{\circ} \mathrm{C}$ in a sealed NMR tube for $6 \mathrm{~h}$. ${ }^{1} \mathrm{H}$ and ${ }^{31} \mathrm{P}\left\{{ }^{1} \mathrm{H}\right\} N M R$ analyses showed the presence of a mixture of starting material, free $\mathrm{PMe}_{2} \mathrm{Ph}$ (Me resonance at $\delta 1.12$ in the ${ }^{1} \mathrm{H}$ spectrum and resonance at $\delta-45.5$ in the ${ }^{31} \mathrm{P}\left\{{ }^{1} \mathrm{H}\right\}$ spectrum), and $\mathrm{CpMoCl}\left(\mathrm{PMe} \mathrm{Ph}_{2}\right.$ (paramagnetically shifted resonances identical with those listed above). Continued heating resulted in a complete loss of the paramagnetically shifted peaks and to the formation of a complicated mixture of diamagnetic products which were not further investigated $\left({ }^{1} \mathrm{H}\right.$ NMR resonances in the $\mathrm{Cp}$ region at $\delta 5.24,4.66,4.46$, 4.36, and 4.04).

Synthesis of Cp*MoCl(PMes) 2 (3). $\mathrm{Cp}^{*} \mathrm{MoCl}_{4}(0.511 \mathrm{~g}$, $1.37 \mathrm{mmol}$ ) was added to a THF solution ( $40 \mathrm{~mL}$ ) of amalgamated $\mathrm{Na}(0.098 \mathrm{~g}, 4.26 \mathrm{mmol}$, in $9 \mathrm{~g}$ of $\mathrm{Hg})$ and $\mathrm{PMe}_{3}(0.284$ $\mathrm{mL}, 2.74 \mathrm{mmol}$ ). After it was stirred overnight, the resulting yellow-brown solution was evaporated to dryness, the residue extracted with heptane $(25 \mathrm{~mL})$, and the extract filtered through Celite until the washings were colorless. The compound could not be crystallized out of solutions of saturated hydrocarbons, and these solutions were therefore used directly for the derivatization reactions with $\mathrm{CO}, \mathrm{H}_{2}$, and $\mathrm{PMe}_{3}$ (vide infra). The concentration of $\mathrm{Cp} * \mathrm{MoCl}\left(\mathrm{PMe}_{3}\right)_{2}$ was determined by reacting an aliquot of the heptane solution with $\mathrm{H}_{2}$ to afford $\mathrm{Cp} * \mathrm{MoCl}\left(\mathrm{H}_{2}\left(\mathrm{PMe}_{3}\right)_{2}\right.$ quantitatively and gas-volumetrically measuring the amount of gas absorbed. On the basis of this procedure the yield was $41 \%$. ${ }^{1} \mathrm{H} N M R\left(\mathrm{C}_{6} \mathrm{D}_{6}, \delta\right): 44.8(\mathrm{br} \mathrm{s}$, $\left.\mathrm{w}_{1 / 2}=105 \mathrm{~Hz}, 15 \mathrm{H}, \mathrm{C}_{5} \mathrm{Me}_{5}\right), 17.8\left(\mathrm{br} \mathrm{s}, \mathrm{w}_{1 / 2}=55 \mathrm{~Hz}, 18 \mathrm{H}\right.$,

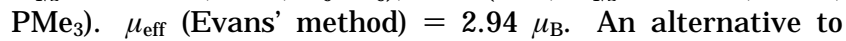
amalgamated $\mathrm{Na}$ is using $\mathrm{Na}$ sand ( $3 \mathrm{~mol} / \mathrm{mol}$ of $\mathrm{Cp} * \mathrm{MoCl}_{4}$ ) and naphthalene $\left(0.3-0.5 \mathrm{~mol} / \mathrm{mol}\right.$ of $\left.\mathrm{Cp}^{*} \mathrm{MoCl}_{4}\right)$.

Synthesis of $\mathrm{Cp} * \mathrm{MoCl}\left(\mathrm{PMe}_{2} \mathrm{Ph}\right)_{2}$ (4). In a procedure identical with that described above for the preparation of $\mathbf{3}$,

(23) Poli, R.; Owens, B. E.; Krueger, S. T.; Rheingold, A. L. Polyhedron 1992, 11, 2301-2312.
$\mathrm{Cp}^{*} \mathrm{MoCl}_{4}(0.105 \mathrm{~g}, 0.282 \mathrm{mmol})$ was added to a THF solution $(15 \mathrm{~mL})$ of amalgamated $\mathrm{Na}(0.021 \mathrm{~g}, 0.913 \mathrm{mmol}$, in $2 \mathrm{~g}$ of $\mathrm{Hg})$ and $\mathrm{PM} \mathrm{e}_{2} \mathrm{Ph}(0.080 \mathrm{~mL}, 0.564 \mathrm{mmol})$. After it was stirred overnight, the resulting orange-brown solution was evaporated to dryness and the residue was extracted with heptane (20 $\mathrm{mL}$ ) and filtered through Celite until the washings were colorless. The compound could not be crystallized out of solutions of saturated hydrocarbons, and these solutions were therefore used directly for the derivatization reactions with $\mathrm{CO}, \mathrm{H}_{2}$, and $\mathrm{PMe}_{3}$ (vide infra). ${ }^{1} \mathrm{H} \mathrm{NMR}\left(\mathrm{C}_{6} \mathrm{D}_{6}, \delta\right): 71$ (br $\mathrm{s}$, $\left.w_{1 / 2}=230 \mathrm{~Hz}, 15 \mathrm{H}, \mathrm{C}_{5} \mathrm{Me}_{5}\right), 16.3$ and $15.3\left(1: 1 \mathrm{br} \mathrm{s}, \mathrm{w}_{1 / 2}=\right.$ $115 \mathrm{~Hz}, 12 \mathrm{H}, \mathrm{PMe}_{2} \mathrm{Ph}$ ). $8.9\left(\mathrm{~s}, \mathrm{w}_{1 / 2}=22 \mathrm{~Hz}, 2 \mathrm{H}, \mathrm{p}-\mathrm{Ph}\right), 7.8$ $\left(\mathrm{s}, \mathrm{w}_{1 / 2}=26 \mathrm{~Hz}, 4 \mathrm{H}, \mathrm{m}-\mathrm{Ph}\right), 6.1\left(\mathrm{~s}, \mathrm{w}_{1 / 2}=150 \mathrm{~Hz}, 4 \mathrm{H}, \mathrm{o}-\mathrm{Ph}\right)$.

Synthesis of Cp*MoCl(dppe) (5). $\mathrm{Cp}^{*} \mathrm{MoCl}_{4}(0.234 \mathrm{~g}$, $0.627 \mathrm{mmol}$ ) was added to $\mathrm{Na}(0.049 \mathrm{~g}, 2.13 \mathrm{mmol})$, naphthalene $(0.015 \mathrm{~g}, 0.117 \mathrm{mmol})$, dppe $(0.249 \mathrm{~g}, 0.625 \mathrm{mmol})$, and THF (15 mL). After it was stirred for 2 days, the orange solution was evaporated to dryness. The residue was extracted with hot heptane $(4 \times 10 \mathrm{~mL})$ and the extract filtered through Celite. The solution was placed at $-80{ }^{\circ} \mathrm{C}$ overnight, which precipitated an orange microcrystalline solid. The solid was filtered, dried, and isolated. Yield: $0.260 \mathrm{~g}, 62 \%$. Anal. Calcd for $\mathrm{C}_{36} \mathrm{H}_{39} \mathrm{ClM} \mathrm{oP}_{2}$ : C, 65.02; $\mathrm{H}, 5.91$. Found: $\mathrm{C}, 65.19 ; \mathrm{H}, 6.01$. ${ }^{1} \mathrm{H}$ NMR $\left(\mathrm{C}_{6} \mathrm{D}_{6}, \delta\right): 75.5\left(\mathrm{br} \mathrm{s}, \mathrm{w}_{1 / 2}=50 \mathrm{~Hz}, 4 \mathrm{H}\right.$, o-Ph), 62.6 (br s, $\left.\mathrm{w}_{1 / 2}=150 \mathrm{~Hz}, 15 \mathrm{H}, \mathrm{C}_{5} \mathrm{Me}_{5}\right) .15 .2$ and $11.9\left(\mathrm{~s}, \mathrm{w}_{1 / 2}=22\right.$ $\mathrm{Hz}, 8 \mathrm{H}, \mathrm{m}-\mathrm{Ph}$ ), 14.6 (br s, $\mathrm{w}_{1 / 2}=90 \mathrm{~Hz}, 4 \mathrm{H}, \mathrm{o}-\mathrm{Ph}$ ), 6.4 and $4.3(\mathrm{~s}, 4 \mathrm{H}, \mathrm{p}-\mathrm{Ph}),-1.2\left(\mathrm{br}, \mathrm{w}_{1 / 2}=118 \mathrm{~Hz}, 4 \mathrm{H}, \mathrm{Ph}_{2} \mathrm{PCH}_{2} \mathrm{CH}_{2^{-}}\right.$ $\left.\mathrm{PPh}_{2}\right) . \mu_{\text {eff }}=2.65 \mu_{\mathrm{B}}$. A single crystal for $\mathrm{X}$-ray analysis of $\mathrm{Cp*MoCl}$ (dppe) was obtained by dissolving the crude product in hot heptane, filtering, and cooling the solution to room temperature slowly in an oil bath.

Thermal Decomposition of 3. A sample of $\mathbf{3}$ prepared as described above was dissolved in $\mathrm{C}_{6} \mathrm{D}_{6}$ and the solution sealed in an NMR tube and heated to $85^{\circ} \mathrm{C}$ for $1 / 2 \mathrm{~h}$, then an additional $2 \mathrm{~h}$ at $100{ }^{\circ} \mathrm{C}$, and finally to $135^{\circ} \mathrm{C}$ with ${ }^{1} \mathrm{H}$ and ${ }^{31} \mathrm{P}$ NMR monitoring after each heating. After the complete heating period the ${ }^{1} \mathrm{H} N \mathrm{NM}$ indicated the complete decomposition of 3. The final ${ }^{1} \mathrm{H}$ and ${ }^{31} \mathrm{P}$ NMR spectra showed thetypical resonances ${ }^{24}$ of $\mathrm{Cp} * \mathrm{MoH}\left(\mathrm{PMe}_{3}\right)_{3}$.

Reaction of $\mathrm{Cp}^{*} \mathrm{MoCl}_{2} \mathrm{~L}_{2}$ with $\mathrm{Na}$. (a) $\mathbf{L}=\mathrm{PMe}_{3}$. Equimolar quantities of $\mathrm{Cp} * \mathrm{MoCl}_{2}\left(\mathrm{PMe}_{3}\right)_{2}$ and amalgamated $\mathrm{Na}$ (ca. $0.5 \%$ ) were allowed to react in THF (ca. $0.02 \mathrm{M}$ ) with ${ }^{1} \mathrm{H}$ NMR monitoring by periodically withdrawing an aliquot of the solution, evaporating it to dryness, and redissolving it in the NMR solvent $\left(C_{6} D_{6}\right)$. After $1-2$ days, the ${ }^{1} \mathrm{H} N M R$ spectrum indicated the complete disappearance of the resonance at $\delta-2.3$ of $\mathrm{Cp}^{*} \mathrm{M} \mathrm{OCl}_{2}\left(\mathrm{PMe}_{3}\right)_{2}$ and conversion to the 16electron $\mathrm{Cp} * \mathrm{MoCl}\left(\mathrm{PMe}_{3}\right)_{2}$ complex (3).

(b) $\mathbf{L}=\mathbf{P M e} 2 \mathbf{P h}$. Equimolar quantities of $\mathrm{Cp} * \mathrm{MoCl}_{2}\left(\mathrm{PMe}_{2}\right.$ $\mathrm{Ph})_{2}$ and amalgamated $\mathrm{Na}$ (ca. $0.5 \%$ ) were allowed to react in THF (ca. $0.02 \mathrm{M}$ ) with ${ }^{1} \mathrm{H}$ NMR monitoring by periodically withdrawing an aliquot of the solution, evaporating it to dryness, and redissolving it in the NMR solvent $\left(\mathrm{C}_{6} \mathrm{D}_{6}\right)$. After 1-2 days the ${ }^{1} \mathrm{H}$ NMR spectrum indicated the complete conversion to the 16-el ectron $\mathrm{Cp} * \mathrm{MoCl}\left(\mathrm{PMe}_{2} \mathrm{Ph}\right)_{2}$ compl ex (4). Solutions of this compound were used directly for the derivatization reactions with $\mathrm{CO}, \mathrm{H}_{2}$, and $\mathrm{PMe}_{3}$ (vide infra).

Thermal Treatment of $\mathbf{C p} * \mathbf{M o C l}\left(\mathrm{PMe}_{3}\right)_{3}$. A sample of $\mathrm{Cp} * \mathrm{MoCl}\left(\mathrm{PMe}_{3}\right)_{3}(67 \mathrm{mg}, 0.135 \mathrm{mmol})$ was dissolved in $\mathrm{C}_{6} \mathrm{D}_{6}$ (ca. $2 \mathrm{~mL}$ ). The resulting solution was warmed to $60^{\circ} \mathrm{C}$ in a sealed NMR tube with periodical monitoring by ${ }^{1} \mathrm{H}$ and ${ }^{31} \mathrm{P}$ $\left\{{ }^{1} \mathrm{H}\right\}$ NMR. After $5.5 \mathrm{~h},{ }^{1} \mathrm{H}$ and ${ }^{31} \mathrm{P}\left\{{ }^{1} \mathrm{H}\right\}$ NMR analyses showed the presence of a mixture of starting material, free $\mathrm{PMe}_{3}$, and compound 3. After a total of $17 \mathrm{~h}$ of heating a mixture similar to that before was observed, but the resonances of $\mathbf{3}$ had diminished in intensity and new resonances of the thermal decomposition product of $\mathbf{3}$ (vide supra) were present as well as an increase in the resonance at $\delta-2.3$ for $\mathrm{Cp}^{*} \mathrm{MoCl}_{2}\left(\mathrm{PMe}_{3}\right)_{2}$.

Reaction between $\mathrm{Cp}^{*} \mathrm{MoCIL}_{2}$ and $\mathrm{CO}$. (a) $\mathbf{L}=\mathrm{PMe}_{3}$. Formation of trans-Cp*MoCl$\left(\mathrm{PMe}_{3}\right)_{2}(\mathrm{CO})(6)$. A solution

(24) Abugideiri, F.; Kelland, M. A.; Poli, R. Organometallics 1992, 11, 1311-1318. 
Table 1. Crystal Data for Compounds 1, 5, and 7

\begin{tabular}{|c|c|c|c|}
\hline $\begin{array}{l}\text { compd } \\
\text { formula }\end{array}$ & $\begin{array}{l}\mathrm{CpMoCl}\left(\mathrm{PMe}_{2} \mathrm{Ph}\right)_{3}, \mathbf{1} \\
\mathrm{C}_{29} \mathrm{H}_{38} \mathrm{ClMoP}{ }_{3}\end{array}$ & $\begin{array}{l}\mathrm{Cp} * \mathrm{MoCl}(\text { dppe), } 5 \\
\mathrm{C}_{36} \mathrm{H}_{39} \mathrm{ClM} \mathrm{PP}_{2}\end{array}$ & $\begin{array}{l}\mathrm{Cp} * \mathrm{MoCl}(\mathrm{CO})\left(\mathrm{PMe}_{2} \mathrm{Ph}\right)_{2,} 7 \\
\mathrm{C}_{27} \mathrm{H}_{37} \mathrm{ClMOOP} 2\end{array}$ \\
\hline & 610.89 & 665.00 & 570.93 \\
\hline space group & $\mathrm{P} 21 / \mathrm{n}$ & $\mathrm{P} 2{ }_{1} / \mathrm{n}$ & $\mathrm{P} 2_{1} / \mathrm{C}$ \\
\hline a, $\AA$ & $11.7902(8)$ & $11.1404(12)$ & $9.572(2)$ \\
\hline $\mathrm{b}, \AA$ & $15.2863(11)$ & $17.628(2)$ & $13.461(2)$ \\
\hline$c, \AA$ & $16.2122(11)$ & $16.936(2)$ & $21.452(3)$ \\
\hline$\beta$, deg & $105.288(6)$ & 107.922(9) & $97.84(2)$ \\
\hline$\vee, \AA^{3}$ & $2818.5(3)$ & $3164.7(5)$ & $2738(2)$ \\
\hline Z & 4 & 4 & 4 \\
\hline $\mathrm{d}_{\mathrm{a}, \mathrm{g}} \mathrm{g} / \mathrm{cm}^{3}$ & 1.440 & 1.396 & 1.38 \\
\hline$\mu(\mathrm{M} \circ \mathrm{K} \alpha), \mathrm{cm}^{-1}$ & 7.44 & 6.24 & 7.02 \\
\hline $\begin{array}{l}\text { radiation (monochromated } \\
\text { in incident beam) }\end{array}$ & $\operatorname{MoK} \alpha(\lambda=0.71073 \AA)$ & $\operatorname{MoK} \alpha(\lambda=0.71073 \AA)$ & $\operatorname{MoK} \alpha(\lambda=0.71073 \AA)$ \\
\hline temp, $\mathrm{K}$ & 153 & 153 & 296 \\
\hline $\begin{array}{l}\text { transmissn factors: } \max , \\
\text { min }\end{array}$ & $0.9686,0.8644$ & $0.9627,0.8029$ & $1.000,0.958$ \\
\hline$R^{a}$ & 0.0611 & 0.0365 & 0.0459 \\
\hline$R w^{b}$ & 0.1067 & 0.0812 & 0.0551 \\
\hline
\end{tabular}

${ }^{\text {a }} \mathrm{R}=\sum|| \mathrm{F}_{\mathrm{o}}|-| \mathrm{F}_{\mathrm{c}}|| / \sum\left|\mathrm{F}_{\mathrm{o}}\right| \cdot{ }^{\mathrm{b}} \mathrm{R}_{\mathrm{w}}=\left[\sum \mathrm{W}\left(\left|\mathrm{F}_{\mathrm{o}}\right|-\left|\mathrm{F}_{\mathrm{c}}\right|\right)^{2} / \sum \mathrm{w}\left|\mathrm{F}_{\mathrm{o}}\right|^{2}\right]^{1 / 2} ; \mathrm{w}=1 / \sigma^{2}\left(\left|\mathrm{~F}_{\mathrm{o}}\right|\right)$.

of $\mathrm{Cp} * \mathrm{MoCl}\left(\mathrm{PMe}_{3}\right)_{2}$ obtained in situ as described above from $0.660 \mathrm{mmol}$ of $\mathrm{Cp}^{*} \mathrm{MoCl}_{2}\left(\mathrm{PMe}_{3}\right)_{2}$ was evaporated to dryness, and the residue was extracted in pentane $(20 \mathrm{~mL})$. The resulting solution was filtered and then exposed to $\mathrm{CO}$ at 1 atm. The formation of a brown precipitate occurred immediately, which was then filtered off. Spectroscopic investigations of the mother liquor indicated the presence of compound 6. $\mathrm{MS}(\mathrm{Cl}$, negative ions; $\mathrm{m} / \mathrm{e})$ : $448\left([\mathrm{M}]^{-}, 100 \%\right)$, $372\left([\mathrm{M}]^{-}-\mathrm{PMe}_{3}, 93 \%\right)$. IR (pentane, $\left.\mathrm{Cm}^{-1}\right)$ : 1786. ${ }^{1} \mathrm{H} \mathrm{NMR}$ $\left(\mathrm{C}_{6} \mathrm{D}_{6}, \delta\right): 1.66(\mathrm{~s}, 15 \mathrm{H}, \mathrm{Cp} *), 1.30\left(\mathrm{vt}, \mathrm{J} \mathrm{PH}=4 \mathrm{~Hz}, 18 \mathrm{H}, \mathrm{PMe}_{3}\right)$. ${ }^{31} \mathrm{P}\left\{{ }^{1} \mathrm{H}\right\} \mathrm{NMR}\left(\mathrm{C}_{6} \mathrm{D}_{6}, \delta\right): 18.5$.

(b) $\mathbf{L}=\mathbf{P M e}_{2} \mathbf{P h}$. Formation of trans-Cp*MoCl(PMe$\mathbf{P h})_{2}(\mathbf{C O})$ (7). A solution of $\mathrm{Cp} * \mathrm{MoCl}\left(\mathrm{PMe}_{2} \mathrm{Ph}\right)_{2}$ obtained in situ as described above from $0.520 \mathrm{mmol}$ of $\mathrm{Cp} * \mathrm{MoCl}_{2}\left(\mathrm{PMe}_{2}\right.$ $\mathrm{Ph})_{2}$ was evaporated to dryness, and the residue was extracted in ether $(20 \mathrm{~mL})$. The resulting solution was filtered and then exposed to $\mathrm{CO}$ at $1 \mathrm{~atm}$. The solution immediately changed col or from yellow-brown to orange-brown. Cooling to $-20^{\circ} \mathrm{C}$ over 1 week afforded $65 \mathrm{mg}$ of compound 7 ( $27 \%$ yield), which was isolated by decanting off the mother liquor and drying under vacuum. Anal. Calcd for $\mathrm{C}_{27} \mathrm{H}_{37} \mathrm{ClMoOP}_{2}$ : $\mathrm{C}, 56.80 ; \mathrm{H}$, 6.53; $\mathrm{Cl}, 6.21$. Found: $\mathrm{C}, 56.4 ; \mathrm{H}, 6.9 ; \mathrm{Cl}, 6.9$. IR (pentane, $\left.\mathrm{cm}^{-1}\right): 1793 .{ }^{1} \mathrm{H} N M R\left(\mathrm{C}_{6} \mathrm{D}_{6}, \delta\right): 7.79\left(\mathrm{~m}, 4 \mathrm{H}, \mathrm{PMe} \mathrm{e}_{2} \mathrm{Ph}\right), 7.08$ (m, $6 \mathrm{H}, \mathrm{PMe}_{2} \mathrm{Ph}$ ), 1.52 (s, 15H, Cp*), 1.44 (overlap of $2 \mathrm{vt}, 12$ $\left.\mathrm{H}, \mathrm{PMe} \mathrm{e}_{2} \mathrm{Ph}\right) .{ }^{31} \mathrm{P}\left\{{ }^{1} \mathrm{H}\right\} N M R\left(\mathrm{C}_{6} \mathrm{D}_{6}, \delta\right):$ 22.0. A single crystal for X-ray analysis of $\mathrm{Cp} * \mathrm{MoCl}\left(\mathrm{PMe}_{2} \mathrm{Ph}\right)_{2}(\mathrm{CO})$ was obtained by cooling a pentane solution to $-80^{\circ} \mathrm{C}$.

Reaction between $\mathrm{Cp}^{*} \mathrm{MoCIL}_{2}$ and $\mathrm{H}_{2}$. (a) $\mathbf{L}=\mathrm{PMe}_{3}$. Preparation of $\mathbf{C p} * \mathrm{MoClH}_{\mathbf{2}}\left(\mathrm{PMe}_{3}\right)_{\mathbf{2}}$ (8). Cp*MoCl$\left(\mathrm{PMe}_{3}\right)_{2^{-}}$ $\left(\mathrm{N}_{2}\right)(0.340 \mathrm{~g}, 0.761 \mathrm{mmol})$ was dissolved in heptane $(20 \mathrm{~mL})$ and the solution exposed to an atmosphere of $\mathrm{H}_{2}$. After the blue solution was heated to $45^{\circ} \mathrm{C}$ for $1 \mathrm{~h}$, the sol ution became red. The absence of $v_{\mathrm{N}-\mathrm{N}}$ in the IR confirmed the complete consumption of the starting material. The heptane solution was concentrated to half the original volume and placed at $-80{ }^{\circ} \mathrm{C}$ overnight, precipitating a red-brown solid. The solid was filtered and dried under vacuum. Yield: $0.140 \mathrm{~g}, 44 \%$. Anal. Calcd for $\mathrm{C}_{16} \mathrm{H}_{35} \mathrm{ClMoP}_{2}$ : $\mathrm{C}, 45.67 ; \mathrm{H}$, 8.39. Found: $\mathrm{C}$, 45.56; $\mathrm{H}, 8.39$. ${ }^{1} \mathrm{H} N M R\left(\mathrm{C}_{6} \mathrm{D}_{6}, \delta\right): 1.76\left(\mathrm{~s}, 15 \mathrm{H}, \mathrm{C}_{5} \mathrm{Me}_{5}\right), 1.32$ $\left(\mathrm{d}, 18 \mathrm{H}, \mathrm{J}_{\mathrm{PH}}=9 \mathrm{~Hz}, \mathrm{PMe}_{3}\right),-2.83\left(\mathrm{t}, 2 \mathrm{H}, \mathrm{J} \mathrm{PH}=50 \mathrm{~Hz}, \mathrm{MoH}_{2}\right.$ ). ${ }^{31} \mathrm{P}\left\{\right.$ selective $\left.{ }^{1} \mathrm{H}\right\} \mathrm{NMR}(\delta): 11.0(\mathrm{t}, \mathrm{J} \mathrm{PH}=38 \mathrm{~Hz})$.

This compound was also generated by an alternative method, i.e. addition of $\mathrm{H}_{2}$ to $\mathrm{Cp} * \mathrm{MoCl}\left(\mathrm{PMe}_{3}\right)_{2}$, although it was not isolated from this procedure. A solution of $\mathrm{Cp} * \mathrm{MoCl}-$ $\left(\mathrm{PMe}_{3}\right)_{2}$ obtained in situ as described above from $0.44 \mathrm{mmol}$ of $\mathrm{Cp} * \mathrm{MoCl}_{2}\left(\mathrm{PMe}_{3}\right)_{2}$ was evaporated to dryness, and the residue was extracted in heptane $(20 \mathrm{~mL})$ and filtered. The resulting solution was then stirred at room temperature under an atmosphere of $\mathrm{H}_{2}$, resulting in no apparent color change. After $3 \mathrm{~h}$, an aliquot of the solution was inspected by NMR after evaporation to dryness and redissolution in $\mathrm{C}_{6} \mathrm{D}_{6}$, confirming the formation of compound $\mathbf{8}$ as the major product. The ${ }^{1} \mathrm{H} N M R$ also showed the presence of $\mathrm{Cp}^{*} \mathrm{MoCl}_{2}\left(\mathrm{PMe}_{3}\right)_{2}$ (broad resonance at $\delta-2.3$ ), which was present prior to the reaction with $\mathrm{H}_{2}$.

(b) $\mathbf{L}=\mathbf{P M e}_{2} \mathbf{P h}$. Formation of Cp*MoCIH $\mathbf{H}_{2}(\mathbf{P M e} 2 \mathrm{Ph})_{2}$ (9). A solution of $\mathrm{Cp} * \mathrm{MoCl}(\mathrm{PMe} P \mathrm{Ph})_{2}$ obtained in situ as described above from $0.52 \mathrm{mmol}$ of $\mathrm{Cp} * \mathrm{MoCl}_{2}\left(\mathrm{PMe}_{2} \mathrm{Ph}\right)_{2}$ was evaporated to dryness, and the residue was extracted in heptane $(20 \mathrm{~mL})$ and the extract filtered. The resulting solution was then stirred at room temperature under an atmosphere of $\mathrm{H}_{2}$, resulting in no apparent col or change. After $3 \mathrm{~h}$, an aliquot of the solution was inspected by NMR after evaporation to dryness and redissol ution in $\mathrm{C}_{6} \mathrm{D}_{6}$, confirming the formation of compound 9 as the major product. ${ }^{1} \mathrm{H}$ NMR $\left(\mathrm{C}_{6} \mathrm{D}_{6}, \delta\right): 1.71\left(\mathrm{~s}, 15 \mathrm{H}, \mathrm{C}_{5} \mathrm{Me}_{5}\right), 1.46(\mathrm{~d}, 12 \mathrm{H}$, J $\mathrm{PH}=10 \mathrm{~Hz}$, $\left.\mathrm{PMe}_{2} \mathrm{Ph}\right),-2.23\left(\mathrm{t}, 2 \mathrm{H}, \mathrm{J} \mathrm{PH}=50 \mathrm{~Hz}, \mathrm{MoH}_{2}\right)$. ${ }^{31} \mathrm{P}$ \{selective${ }^{1} \mathrm{H}$ \} NMR $(\delta): 21.8(\mathrm{t}, \mathrm{J} \mathrm{PH}=34 \mathrm{~Hz})$. Other resonances in the ${ }^{1} \mathrm{H}$ and ${ }^{31} \mathrm{P}$ NMR spectra were due to free $\mathrm{PMe} \mathrm{e}_{2} \mathrm{Ph}$ and to other unidentified diamagnetic and paramagnetic complexes.

X-ray Crystallography. (a) $\mathrm{CpMoCl}\left(\mathrm{PMe}_{2} \mathrm{Ph}\right)_{3}$ (1). A reddish purple crystal with dimensions $0.225 \times 0.200 \times 0.038$ $\mathrm{mm}$ was placed and optically centered on the Enraf-Nonius CAD-4 diffractometer. The parameters and crystal orientation matrix were determined from 25 reflections in the range 17.5 $<\theta<19.8^{\circ}$ and confirmed with axial photographs. Data were collected with $\omega / 2 \theta$ scans over the range $2.25<\theta<24.0^{\circ}$. No decay correction was necessary. An absorption correction was applied on the basis of crystal faces with transmission factors ranging from 0.8644 to 0.9686 . The uniquely determined centrosymmetric monoclinic space group $\mathrm{P} 21 / \mathrm{n}$ was indicated by the systematic absences from the data and confirmed by the successful completion of the structure. After data reduction and correction for Lorentz and polarization factors, direct methods successfully located all the non-hydrogen atoms. All hydrogen atoms were found from an initial difference-F ourier map; however, hydrogen atoms attached to carbon atoms were placed instead in calculated positions, with $\mathrm{d}\left(\mathrm{C}-\mathrm{H}_{3}\right)=0.980$ $\AA$ and $U_{H}=1.5 \mathrm{U}$ (parent) and with aromatic $\mathrm{d}(\mathrm{C}-\mathrm{H})=0.950$ $\AA$ and $U_{H}=1.2 \mathrm{U}$ (parent). All of the non-hydrogen atoms were refined anisotropically by full-matrix least-squares cycles. Crystal data are reported in Table 1, and selected bond distances and angles are collected in Table 2.

(b) $\mathbf{C p} * \mathrm{MoCl}(\mathrm{dppe)}$ (5). A reddish purple crystal with dimensions $0.375 \times 0.375 \times 0.050 \mathrm{~mm}$ was placed and optically centered on the E nraf-N onius CAD-4 diffractometer. The cell parameters and crystal orientation matrix were determined from 25 reflections in the range $16.0<\theta<19.3^{\circ}$; these constants were confirmed with axial photographs. Data were collected $(\mathrm{MoK} \alpha)$ with $\omega / 2 \theta$ scans over the range $2.25<\theta<$ $24.0^{\circ}$. No decay correction was necessary. Data were cor- 
Table 2. Selected Intramolecular Distances $(\AA)$ and Angles (deg) for $\mathrm{CpMoCl}\left(\mathrm{PMe}_{2} \mathrm{Ph}\right)_{3}$ (1)

\begin{tabular}{|c|c|c|c|}
\hline $\begin{array}{l}\mathrm{Mo}(1)-\mathrm{CNT}^{\mathrm{a}} \\
\mathrm{Mo}(1)-\mathrm{P}(2) \\
\mathrm{Mo}(1)-\mathrm{P}(3)\end{array}$ & $\begin{array}{l}1.974(9) \\
2.453(2) \\
2.459(2)\end{array}$ & $\begin{array}{l}\mathrm{Mo}(1)-\mathrm{P}(1) \\
\mathrm{Mo}(1)-\mathrm{Cl}(1)\end{array}$ & $\begin{array}{l}2.486(2) \\
2.585(2)\end{array}$ \\
\hline $\begin{array}{l}\mathrm{CNT}^{\mathrm{a}}-\mathrm{Mo}(1)-\mathrm{Cl}(1) \\
\mathrm{CNT}^{\mathrm{a}}-\mathrm{Mo}(1)-\mathrm{P}(1) \\
\mathrm{CNT}^{\mathrm{a}}-\mathrm{Mo}(1)-\mathrm{P}(2) \\
\mathrm{CNT}^{\mathrm{a}}-\mathrm{Mo}(1)-\mathrm{P}(3) \\
\mathrm{P}(1)-\mathrm{Mo}(1)-\mathrm{P}(2)\end{array}$ & $\begin{array}{l}109.9(2) \\
120.0(3) \\
114.7(3) \\
114.3(2) \\
123.72(8)\end{array}$ & $\begin{array}{l}\mathrm{P}(1)-\mathrm{Mo}(1)-\mathrm{P}(3) \\
\mathrm{P}(2)-\mathrm{Mo}(1)-\mathrm{P}(3) \\
\mathrm{P}(1)-\mathrm{Mo}(1)-\mathrm{Cl}(1) \\
\mathrm{P}(2)-\mathrm{Mo}(1)-\mathrm{Cl}(1) \\
\mathrm{P}(3)-\mathrm{Mo}(1)-\mathrm{Cl}(1)\end{array}$ & $\begin{array}{r}84.01(8) \\
85.20(8) \\
72.75(8) \\
77.79(8) \\
135.74(8)\end{array}$ \\
\hline \multicolumn{4}{|c|}{${ }^{\mathrm{a} C N T}$ is the center of gravity of atoms $\mathrm{C}(1)-\mathrm{C}(5)$. } \\
\hline \multicolumn{4}{|c|}{$\begin{array}{c}\text { Table 3. Selected Bond Distances }(\AA) \text { and Angles } \\
\text { (deg) for Cp*MoCI(dppe) (5) }\end{array}$} \\
\hline $\begin{array}{l}\mathrm{Mo}(1)-\mathrm{CNT}^{\mathrm{a}} \\
\mathrm{Mo}(1)-\mathrm{Cl}(1)\end{array}$ & $\begin{array}{l}1.998(5) \\
2.416(1)\end{array}$ & $\begin{array}{l}\mathrm{Mo}(1)-\mathrm{P}(1) \\
\mathrm{Mo}(1)-\mathrm{P}(2)\end{array}$ & $\begin{array}{l}2.428(1) \\
2.413(1)\end{array}$ \\
\hline $\begin{array}{l}\mathrm{CNT}^{\mathrm{a}}-\mathrm{Mo}(1)-\mathrm{Cl}(1) \\
\mathrm{CNT}^{\mathrm{a}}-\mathrm{Mo}(1)-\mathrm{P}(1) \\
\mathrm{CNT}^{\mathrm{a}}-\mathrm{Mo}(1)-\mathrm{P}(2)\end{array}$ & $\begin{array}{l}120.1(1) \\
136.8(1) \\
129.6(1)\end{array}$ & $\begin{array}{l}\mathrm{Cl}(1)-\mathrm{Mo}(1)-\mathrm{P}(1) \\
\mathrm{Cl}(1)-\mathrm{Mo}(1)-\mathrm{P}(2) \\
\mathrm{P}(1)-\mathrm{Mo}(1)-\mathrm{P}(2)\end{array}$ & $\begin{array}{l}83.59(4) \\
92.94(5) \\
78.71(4)\end{array}$ \\
\hline
\end{tabular}

a CNT is the center of gravity of atoms $C(1)-C(5)$.

rected for Lorentz and polarization factors, and an absorption correction was applied on the basis of crystal faces with transmission factors ranging from 0.8029 to 0.9627 . The uniquely determined centrosymmetric monocl inic space group $\mathrm{P} 21 / \mathrm{n}$ was indicated by the systematic absences from the data and confirmed by the successful completion of the structure. Direct methods successfully located all of the heavy atoms (Mo, $\mathrm{P}, \mathrm{Cl})$ and many of the carbon atoms. All remaining nonhydrogen atoms were found from an initial difference-Fourier map and/or had their positions calculated. Hydrogen atoms were treated as described in the previous section for compound 1. Crystal data are assembled in Table 1, and selected bond distances and angles are collected in Table 3.

(c) $\mathbf{C p} * \mathbf{M o C l}(\mathbf{C O})\left(\mathbf{P M e}_{2} \mathbf{P h}\right)_{2}$ (7). A single crystal was glued to the inside of a thin-walled glass capillary, which was then flame-sealed under dinitrogen and mounted on the diffractometer. The cell determination, data collection, and reduction were carried out as described above for compound 5. The position of the Mo atom was obtained from the analysis of the Patterson map, and the positions of all the other nonhydrogen atoms were revealed by a subsequent DIRDIF run. The structure was then refined by least-squares cycles to convergence with all non-hydrogen atoms anisotropic. The final difference-Fourier map revealed disorder with a minor orientation of the two relative trans $\mathrm{Cl}$ and $\mathrm{CO}$ ligands in the opposite configuration (e.g. the $\mathrm{Cl}$ of the minor species occupies the same coordination position as the $\mathrm{CO}$ of the major species and vice versa). Both major and minor orientations were introduced at variable occupancies, which were refined independently $(\mathrm{Cl}, \mathrm{x} ; \mathrm{CIA}, 1-\mathrm{x} ; \mathrm{C}$ and $\mathrm{O}, \mathrm{y} ; \mathrm{CA}$ and $\mathrm{OA}, 1-\mathrm{y})$. In order to avoid instability, the following distances were re strained with DFIX cards in SHELX76: $\mathrm{Mo}-\mathrm{Cl}=\mathrm{Mo}-\mathrm{ClA}=$ 2.58(5) $\AA$; $\mathrm{Mo}-\mathrm{C}(\mathrm{O})=\mathrm{Mo}-\mathrm{C}(\mathrm{OA})=1.94(2) \AA ; \mathrm{C}(\mathrm{O})-\mathrm{O}=$ $\mathrm{C}(\mathrm{OA})-\mathrm{OA}=1.15(2) \AA$. Refinement converged to $\mathrm{R}=0.0544$ with all atoms except $\mathrm{CIA}$ and the carbonyl $\mathrm{C}$ and $\mathrm{O}$ atoms for both major and minor orientations anisotropic, giving $\mathrm{x}=$ 0.66 and $y=0.74$, confirming the correctness of the model. Finally, $x$ and $y$ were constrained to have the same value as dictated by stoichiometry and the hydrogen atoms were included in calculated positions as described above for the structure of $\mathbf{1}$. Crystal data are reported in Table 1, and selected bond distances and angles are collected in Table 4.

\section{Results}

Synthesis and Spectroscopic Characterization

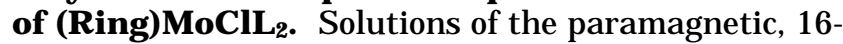
electron (Ring) $\mathrm{MoClL}_{2}$ complexes (Ring $=\mathrm{Cp}$, $\mathrm{L}=\mathrm{PMe}_{2}$ $\mathrm{Ph}$ (2); Ring $=\mathrm{Cp}^{*}, \mathrm{~L}=\mathrm{PMe}_{3}$ (3), $\mathrm{PMe}_{2} \mathrm{Ph}$ (4), $\mathrm{L}_{2}=$
Table 4. Selected Bond Distances $(\AA)$ and Angles (deg) for $\mathrm{Cp} * \mathrm{MoCl}(\mathrm{CO})\left(\mathrm{PMe}_{2} \mathrm{Ph}\right)_{2}$

\begin{tabular}{llll}
\hline $\mathrm{Mo}-\mathrm{Cl}$ & $2.577(5)$ & $\mathrm{Mo}-\mathrm{Cl}(\mathrm{A})$ & $2.616(10)$ \\
$\mathrm{Mo}-\mathrm{P}(1)$ & $2.479(2)$ & $\mathrm{Mo}-\mathrm{P}(2)$ & $2.469(2)$ \\
$\mathrm{Mo}-\mathrm{C}(\mathrm{O})$ & $1.874(11)$ & $\mathrm{Mo}-\mathrm{C}(\mathrm{OA})$ & $1.887(15)$ \\
$\mathrm{Mo}-\mathrm{C}(17)$ & $2.342(8)$ & $\mathrm{Mo}-\mathrm{C}(18)$ & $2.304(8)$ \\
$\mathrm{Mo}-\mathrm{C}(19)$ & $2.298(8)$ & $\mathrm{Mo}-\mathrm{C}(20)$ & $2.352(9)$ \\
$\mathrm{Mo}-\mathrm{C}(21)$ & $2.377(9)$ & $\mathrm{Mo}-\mathrm{CNT}$ & $2.017(9)$ \\
$\mathrm{P}(1)-\mathrm{C}(1)$ & $1.827(8)$ & $\mathrm{P}(1)-\mathrm{C}(2)$ & $1.815(8)$ \\
$\mathrm{P}(1)-\mathrm{C}(3)$ & $1.830(8)$ & $\mathrm{P}(2)-\mathrm{C}(9)$ & $1.833(8)$ \\
$\mathrm{P}(2)-\mathrm{C}(10)$ & $1.841(9)$ & $\mathrm{P}(2)-\mathrm{C}(11)$ & $1.827(7)$ \\
$\mathrm{C}(\mathrm{O})-\mathrm{O}$ & $1.114(15)$ & $\mathrm{C}(\mathrm{OA})-\mathrm{OA}$ & $1.104(17)$ \\
$\mathrm{Cl}-\mathrm{Mo}-\mathrm{P}(1)$ & $79.7(1)$ & $\mathrm{Cl}-\mathrm{Mo}-\mathrm{P}(2)$ & $76.5(1)$ \\
$\mathrm{Cl}-\mathrm{Mo}-\mathrm{C}(\mathrm{O})$ & $130.2(4)$ & $\mathrm{Cl}-\mathrm{Mo}-\mathrm{CNT}$ & $111.9(4)$ \\
$\mathrm{Cl}(\mathrm{A})-\mathrm{Mo}-\mathrm{P}(1)$ & $76.0(2)$ & $\mathrm{Cl}(\mathrm{A})-\mathrm{Mo}-\mathrm{P}(2)$ & $75.6(2)$ \\
$\mathrm{Cl}(\mathrm{A})-\mathrm{Mo}-\mathrm{C}(\mathrm{OA})$ & $128.9(7)$ & $\mathrm{Cl}(\mathrm{A})-\mathrm{Mo}-\mathrm{CNT}$ & $119.1(4)$ \\
$\mathrm{P}(1)-\mathrm{Mo}-\mathrm{P}(2)$ & $116.6(1)$ & $\mathrm{P}(1)-\mathrm{Mo}-\mathrm{C}(\mathrm{O})$ & $76.2(4)$ \\
$\mathrm{P}(1)-\mathrm{Mo}-\mathrm{C}(\mathrm{OA})$ & $76.8(7)$ & $\mathrm{P}(1)-\mathrm{Mo}-\mathrm{CNT}$ & $122.1(4)$ \\
$\mathrm{P}(2)-\mathrm{Mo}-\mathrm{C}(\mathrm{O})$ & $76.6(4)$ & $\mathrm{P}(2)-\mathrm{Mo}-\mathrm{C}(\mathrm{OA})$ & $79.2(7)$ \\
$\mathrm{P}(2)-\mathrm{Mo}-\mathrm{CNT}$ a & $121.2(4)$ & $\mathrm{C}(\mathrm{O})-\mathrm{Mo}-\mathrm{CNT} \mathrm{T}^{\mathrm{a}}$ & $117.8(5)$ \\
$\mathrm{C}(\mathrm{OA})-\mathrm{Mo}-\mathrm{CNT}$ a & $111.9(8)$ & $\mathrm{Mo}-\mathrm{C}(\mathrm{O})-\mathrm{O}$ & $173.4(13)$ \\
$\mathrm{Mo}-\mathrm{C}(\mathrm{OA})-\mathrm{OA}$ & $175(3)$ & & \\
a CNT = centroid of atoms C(17)-C(21). &
\end{tabular}

dppe (5)) were obtained by four different methods: (i) by reduction of $\mathrm{Cp}^{*} \mathrm{MoCl}_{4}$ in the presence of $\mathrm{L}$ (eq 1 ), (ii) by reduction of $C p^{*} \mathrm{MoCl}_{2} \mathrm{~L}_{2}$ (eq 2), (iii) by reduction of $\mathrm{CpMoCl}_{2}$ in the presence of $\mathrm{L}$ (eq 3 ) (this reaction probably proceeds by initial coordination of the phosphine ligand to generate the 17-electron $\mathrm{CpMoCl}_{2} \mathrm{~L}_{2}$ complexes, followed by reduction as for the corresponding $\mathrm{Cp}^{*}$ systems in eq 2), and (iv) by thermal ligand dissociation from the 18-electron complexes $\mathrm{CpMoCl}$ $\left(\mathrm{PMe}_{2} \mathrm{Ph}\right)_{3}$ and $\mathrm{Cp} * \mathrm{MoCl}\left(\mathrm{PMe}_{3}\right)_{3}$ (eq 4).

$$
\begin{aligned}
& \mathrm{Cp} * \mathrm{MoCl}_{4}+3 \mathrm{Na}+2 \mathrm{~L} \stackrel{\mathrm{THF}, \mathrm{Ar}}{\longrightarrow} \mathrm{Cp}^{*} \mathrm{MoClL}_{2}+3 \mathrm{NaCl} \\
& \mathrm{L}=\mathrm{PMe}_{3}, \mathrm{PMe}_{2} \mathrm{Ph} ; \mathrm{L}_{2}=\text { dppe } \\
& \mathrm{Cp}^{*} \mathrm{MoCl}_{2} \mathrm{~L}_{2}+\mathrm{Na} \stackrel{\mathrm{THF}, \mathrm{Ar}}{\longrightarrow} \mathrm{Cp} * \mathrm{MoCl} \mathrm{L}_{2}+\mathrm{NaCl} \\
& \mathrm{L}=\mathrm{PMe}_{3}, \mathrm{PMe}_{2} \mathrm{Ph} \\
& \mathrm{CpMoCl}_{2}+\mathrm{Na}+2 \mathrm{PMe}_{2} \mathrm{Ph} \stackrel{\mathrm{THF}, \mathrm{Ar}}{\longrightarrow} \\
& \mathrm{CpMoCl}\left(\mathrm{PMe}_{2} \mathrm{Ph}\right)_{2}+\mathrm{NaCl} \\
& \text { (Ring)MoClL } 3 \stackrel{\Delta, \mathrm{C}_{6} \mathrm{D}_{6}}{\longrightarrow} \text { (Ring)MoClL } \mathrm{M}_{2}+\mathrm{L} \\
& \text { Ring }=C p, L=\mathrm{PMe}_{2} \mathrm{Ph} \text {; Ring }=\mathrm{Cp} * \mathrm{~L}=\mathrm{PMe}_{3}
\end{aligned}
$$

Compounds 2-4 could not be isolated in the crystalline state and were charcacterized by spectroscopy and by chemical derivatization (vide infra). However, compound $\mathbf{5}$ was isolated as a crystalline solid and characterized by ${ }^{1} \mathrm{H} N M R$, elemental $(\mathrm{C}, \mathrm{H})$ analysis, magnetic susceptibility, and X-ray crystallography.

The ${ }^{1} \mathrm{H}$ NMR spectra for all of the 16-electron complexes show broad paramagnetically shifted resonances. Figure la shows the ${ }^{1} \mathrm{H}$ NMR spectrum of compound 3. The broad resonance $\left(w_{1 / 2}=105 \mathrm{~Hz}\right)$ at $45 \mathrm{ppm}$ is assigned to the $\mathrm{Cp}^{*}$ ligand, whereas the peak at $18 \mathrm{ppm}$ $\left(w_{1 / 2}=55 \mathrm{~Hz}\right)$ is assigned to the $\mathrm{PMe}_{3}$ ligand. The qualitative features of this spectrum are identical in other NMR solvents (i.e. acetone- $d_{6}$ ) or in the presence of THF. As expected, the 16-electron complexes are EPR-silent, since the two possible spin states are $S=1$ and $S=0$. Systems with more than one unpaired electron are generally EPR-inactive due to large zerofield splittings and fast electronic relaxations. Com- 

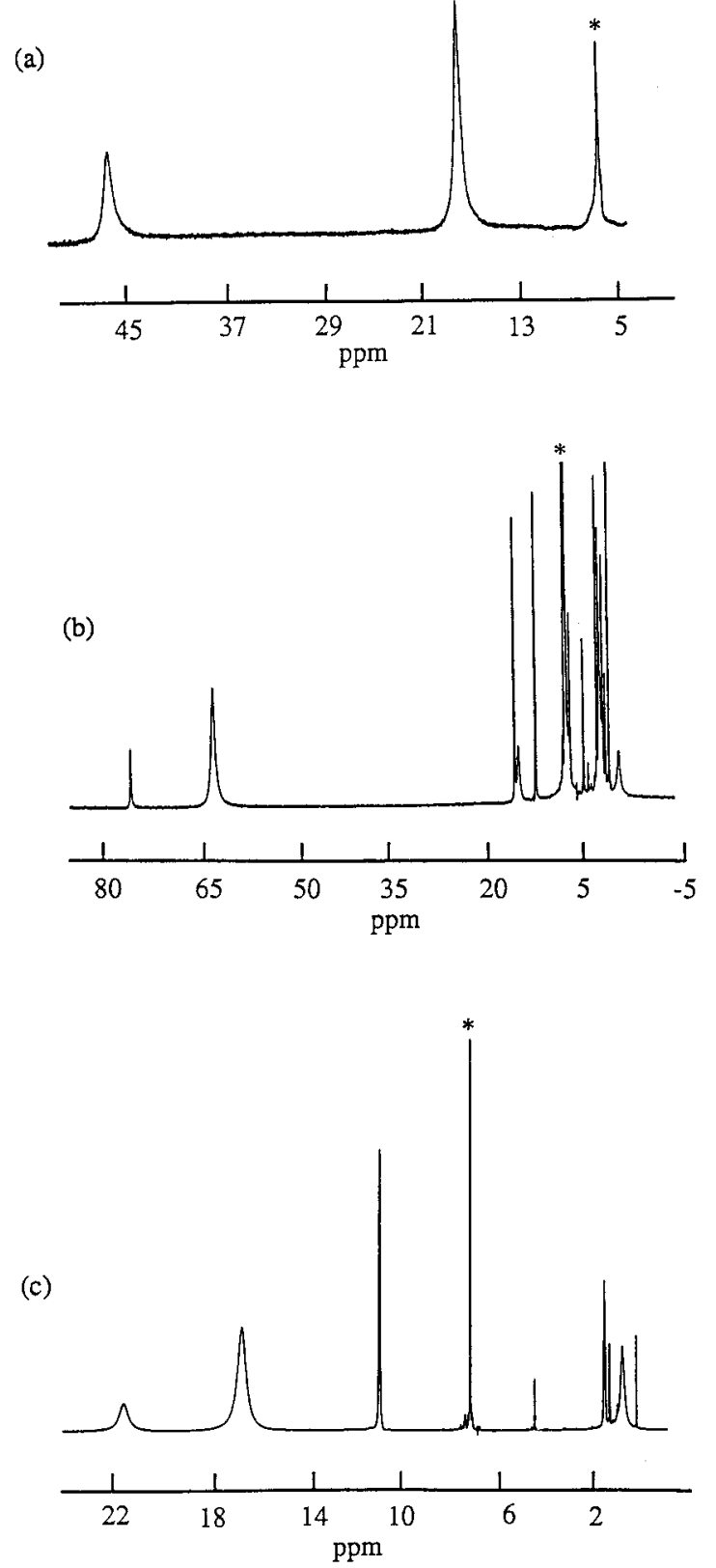

Figure 1. ${ }^{1 \mathrm{H}} \mathrm{NMR}$ of (a) $\mathrm{Cp} * \mathrm{MoCl}\left(\mathrm{PMe}_{3}\right)_{2}$ (3), (b) $\mathrm{Cp}^{*} \mathrm{MoCl}(\mathrm{dppe})$ (5), and (c) $\mathrm{CpMoCl}\left(\mathrm{PMe}_{2} \mathrm{Ph}\right)_{2}$ (2). All spectra were recorded in $\mathrm{C}_{6} \mathrm{D}_{6}$. The starred resonance corresponds to $\mathrm{C}_{6} \mathrm{D}_{5} \mathrm{H}$.

pound $\mathbf{4}$ also shows a broad and strongly shifted $\mathrm{Cp}^{*}$ resonance in the ${ }^{1} \mathrm{H}$ NMR spectrum (at $\delta 71$ with $\mathrm{w}_{1 / 2}$ $=230 \mathrm{~Hz}$ ). The diastereotopic methyl protons of the $\mathrm{PMe}_{2} \mathrm{Ph}$ ligands are obeserved at $\delta 16.3$ and $15.3\left(\mathrm{w}_{1 / 2}\right.$ $=115 \mathrm{~Hz}$ ). The phenyl protons also show paramagnetically shifted and broadened peaks: the ortho protons at $\delta 6.1\left(\mathrm{w}_{1 / 2}=150 \mathrm{~Hz}\right)$, the meta at $\delta 7.8\left(\mathrm{w}_{1 / 2}=\right.$ $26 \mathrm{~Hz})$, and the para at $\delta 8.9\left(\mathrm{w}_{1 / 2}=22 \mathrm{~Hz}\right)$. The assignment is based on relative line widths (the protons closest to the paramagnetic metal center, i.e. ortho, have the broader resonance) and relative intensity (the para protons are half the intensity of the meta protons).

The analysis of the ${ }^{1} \mathrm{H}$ NMR spectrum of compound 5 (see Figure 1b) also deserves some attention, especially with respect to the phenyl protons of the dppe ligand. The broad resonance at $63 \mathrm{ppm}\left(\mathrm{w}_{1 / 2}=150 \mathrm{~Hz}\right)$ is assigned to the Cp* ligand and compares well with that found for $\mathbf{3}$ and $\mathbf{4}$. The symmetry of the molecule dictates two equal sets of phenyl and methylene reso- nances, one set being for the two rings and methylene protons pointing toward the $\mathrm{Cp}$ * ligand and the other set for those directed away from it. As a result, the dppe ligand should exhibit a total of eight resonances in a $4: 4,4: 4,2: 2$, and 2:2 ratio for the two sets of ortho, meta, para, and methylene protons, respectively. The resonances assigned to the ortho protons are at $76 \mathrm{ppm}\left(\mathrm{w}_{1 / 2}\right.$ $=50 \mathrm{~Hz})$ and $15 \mathrm{ppm}\left(\mathrm{w}_{1 / 2}=90 \mathrm{~Hz}\right)$. It is interesting to note the large difference in the shifts of these two resonances, much larger than for all of the other types of protons. This can be attributed to a large difference in through-space dipolar interaction with the electronic spins. The meta and para protons show much less differences in chemical shifts, i.e. 3.0 and 2.1 ppm, respectively.

The preparation of $\mathbf{1}$ follows the procedure previously reported for the preparation of the related $\mathrm{CpMoCl}$ $\left(\mathrm{PMe}_{3}\right)_{3}{ }^{22}$ The yield of this product is low, being crystallized from $\mathrm{Et}_{2} \mathrm{O}$ at low temperatures. A large amount of more soluble material remained in solution, and no additional significant amount of 1 was recovered upon further concentration and cooling. The more soluble material was recovered by crystallization from very concentrated ether solutions (see Experimental Section). It consists of the paramagnetic compound $\mathrm{CpMoCl}\left(\mathrm{PMe}_{2} \mathrm{Ph}\right)_{2}$ (2), along with small amounts of the hydride complex $\mathrm{CpM}$ oH $\left(\mathrm{PMe}_{2} \mathrm{Ph}\right)_{3}$ as an impurity. The latter is recognized from the diagnostic hydride resonance, split into a binomial quartet by coupling to the three equivalent phosphorus nuclei, at $\delta-7.7$ in the ${ }^{1} \mathrm{H}$ NMR spectrum. The ${ }^{1} \mathrm{H}$ NMR spectrum of $\mathbf{2}$ (see Figure 1c), like the other 16-electron complexes described above, shows paramagnetically shifted and broadened resonances. The $\mathrm{Cp}$ ligand was so broadened and/or contact-shifted that it could not be detected. The analysis of the relative intensities and line widths led to the reasonable assignment of the $\delta 16.6\left(\mathrm{w}_{1 / 2}=80\right.$ $\mathrm{Hz}$ ) resonance to the $\mathrm{PMe} 2 \mathrm{Ph}$ methyl protons and the $\delta$ $21.5\left(w_{1 / 2}=79 \mathrm{~Hz}\right), 10.9\left(w_{1 / 2}=25 \mathrm{~Hz}\right)$, and $0.85\left(w_{1 / 2}\right.$ $=42 \mathrm{~Hz}$ ) resonances to the $\mathrm{PMe} P \mathrm{Ph}$ ortho, para, and meta protons, respectively. The thermal treatment of 1 in $C_{6} D_{6}$ for several hours produces an observable quantity of the same paramagnetic product 2 (eq 4). The proposed phosphine dissociation/assodiation process must be sufficiently slow on the NMR time scale because $\mathbf{1}$ and $\mathbf{2}$ are independently observed. The analogous equilibrium between the 18-electron $\mathrm{Cp} * \mathrm{MoCl}\left(\mathrm{PMe}_{3}\right)_{3}$ and the paramagnetic $\mathbf{3}$ is also quite slow. ${ }^{18}$ The exact position of the equilibrium that is established by heating the 18-electron tris(phosphine) compound could not be determined due to the formation of $\mathrm{Cp} * \mathrm{MoCl}_{2}\left(\mathrm{PMe}_{3}\right)_{2}$ as well as $\mathrm{Cp} * \mathrm{MoH}\left(\mathrm{PMe}_{3}\right)_{3}$, the thermal decomposition products of $\mathbf{3}$.

Magnetic Properties. The paramagnetism observed for the solutions of 2-5 (as indicated by the paramagnetically shifted resonances in the ${ }^{1} \mathrm{H}$ NMR) suggests a spin triplet ground state. The solid-state magnetic moment of $\mathbf{5}$ was determined to be $2.65 \mu_{\mathrm{B}}$. This is in excellent agreement with the theoretical spinonly value of $2.83 \mu_{\mathrm{B}}$. As stated above, the other 16electron species could not be crystall ized. However, the magnetic moment of $\mathbf{3}$ could be determined in solution as $\mu_{\text {eff }}=2.93 \mu_{\mathrm{B}}$ by the Evans method. One of the concerns with systems of this type is the presence of a spin equilibrium. This occurs when the energy gap 
(a)

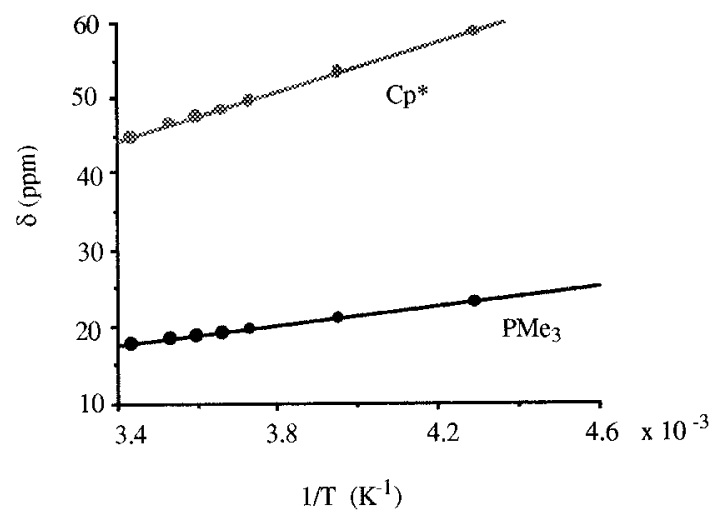

(b)

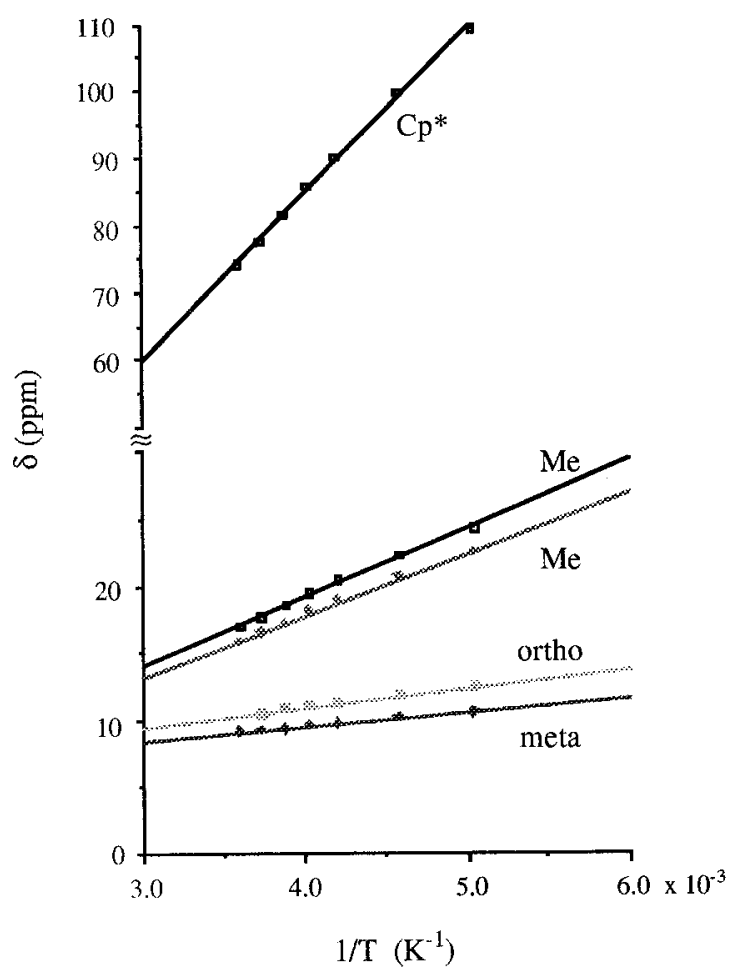

Figure 2. Plot of $\delta$ versus $\mathrm{T}^{-1}$ for (a) $\mathrm{Cp} * \mathrm{MoCl}\left(\mathrm{PMe}_{3}\right)_{2}$ (3) and (b) $\mathrm{Cp} * \mathrm{MoCl}\left(\mathrm{PMe}_{2} \mathrm{Ph}\right)_{2}$ (4).

between the ground state and the excited state is small enough to allow thermal population of the latter. In order to probe for this possibility, variable-temperature NMR experiments were carried out on compounds $\mathbf{3}$ and 4. As the temperature was lowered, the resonances for the paramagnetic protons became broader and more contact-shifted as expected. Figure 2 shows the dependence of the chemical shift versus $T^{-1}$. The observed linear behavior indicates that the system follows CurieWeiss behavior and therefore excludes a significant thermal population of an excited singlet state.

Reaction of $\mathrm{Cp}^{*} \mathrm{MoClL}_{2}$ with $\mathrm{CO}$ and $\mathrm{H}_{2}$. Treatment of solutions of compounds $\mathbf{3}$ and $\mathbf{4}$ with $\mathrm{CO}$ (eq 5) gives rise to formation of the 18-electron $\mathrm{CO}$ adducts $\mathrm{Cp} * \mathrm{MoCl}(\mathrm{CO}) \mathrm{L}_{2}\left(\mathrm{~L}=\mathrm{PMe}_{3}(6), \mathrm{PMe}_{2} \mathrm{Ph}(7)\right)$, and treatment with $\mathrm{H}_{2}$ (eq 6) gives rise to the formation of the products of $\mathrm{H}-\mathrm{H}$ oxidative addition, the $\mathrm{Mo}(\mathrm{IV})$ complexes $\mathrm{Cp}^{*} \mathrm{MoClH}_{2} \mathrm{~L}_{2}\left(\mathrm{~L}=\mathrm{PMe}_{3}\right.$ (8), $\left.\mathrm{PMe}_{2} \mathrm{Ph}(\mathbf{9})\right)$. These 18-electron $\mathrm{H}_{2}$ and $\mathrm{CO}$ adducts are less soluble

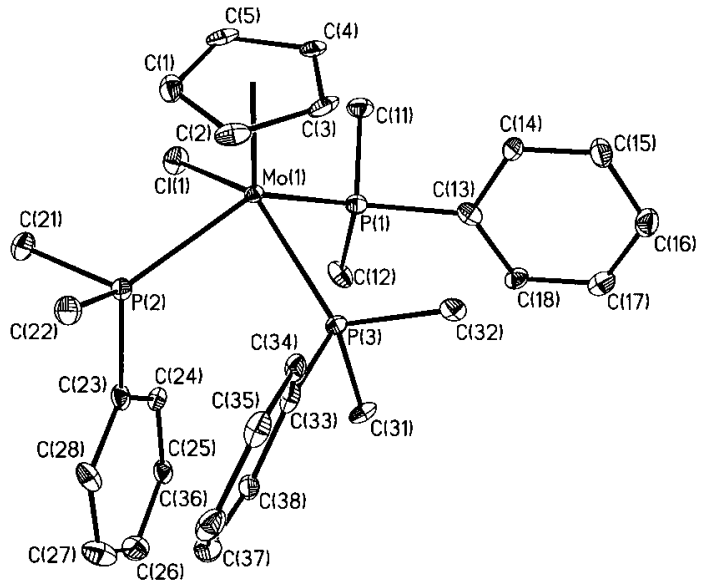

Figure 3. ORTEP diagram of $\mathrm{CpMoCl}\left(\mathrm{PMe}_{2} \mathrm{Ph}\right)_{3}(\mathbf{1})$.

than the 16-electron precursors, al lowing in some cases isolation in the crystalline state. Compound $\mathbf{5}$ also forms a CO adduct, as already described elsewhere. ${ }^{25}$

$$
\begin{aligned}
& \mathrm{Cp}^{*} \mathrm{MoClL}_{2}+\mathrm{CO} \stackrel{\mathrm{THF}}{\longrightarrow} \mathrm{Cp}^{*} \mathrm{MoClL}_{2}(\mathrm{CO}) \\
& \mathrm{L}=\mathrm{PMe}_{3}, \mathrm{PMe}_{2} \mathrm{Ph} \\
& \mathrm{Cp}^{*} \mathrm{MoClL}_{2}+\mathrm{H}_{2} \stackrel{\mathrm{THF}}{\longrightarrow} \mathrm{Cp} * \mathrm{MoCl}(\mathrm{H})_{2} \mathrm{~L}_{2} \\
& \mathrm{~L}=\mathrm{PMe}_{3}, \mathrm{PMe}_{2} \mathrm{Ph}
\end{aligned}
$$

The $\mathrm{CO}$ adducts $\mathbf{6}$ and $\mathbf{7}$ were characterized by IR and ${ }^{1} \mathrm{H}$ and ${ }^{31 P}$ NMR spectroscopy, and by an X-ray analysis of 7. The CO stretching vibrations are observed at 1786 $\mathrm{cm}^{-1}$ for $\mathbf{6}$ and $1793 \mathrm{~cm}^{-1}$ for 7, in agreement with the greater basicity of the $\mathrm{PMe}_{3}$ ligand as compared to $\mathrm{PMe}_{2} \mathrm{Ph}$. Each compound shows a single phosphorous resonance in the ${ }^{31 P}$ NMR and a virtual triplet resonance in the ${ }^{1} \mathrm{H} N M R$ for the phosphine methyl protons, indicating equivalent phosphines in a trans geometry. This structural supposition is further confirmed by the $X$-ray analysis of $\mathbf{7}$ (vide infra).

The ${ }^{1} \mathrm{H}$ and ${ }^{31} \mathrm{P}$ NMR properties of $\mathbf{8}$ and $\mathbf{9}$ are fully consistent with the formation of a classical Mo(IV) dihydride complex with rapidly exchanging $\mathrm{H}$ ligands. Each compound shows a singlet for the Cp* resonance, a doublet for the methyl resonances of the phosphine ligand, and a triplet for the $\mathrm{MoH}_{2}$ resonances, indicating coupling to two equivalent phosphines. The ${ }^{31} \mathrm{P}\left\{{ }^{1} \mathrm{H}-\right.$ selective\} NMR spectra show a single triplet resonance, confirming the conclusion that, on the NMR time scale, the two phosphorus nuclei are equivalent and are coupled to two equivalent hydrides. The NMR properties of these chloro/dihydride complexes correspond quite closely to those of $\left(\mathrm{C}_{5} \mathrm{H}_{4}-\mathrm{i}-\mathrm{Pr}\right) \mathrm{MoClH}_{2}\left(\mathrm{PMe}_{3}\right)_{2}$, which was shown to have a single hydride resonance for the two rapidly exchanging inequivalent classical hydride ligands at room temperature, which decoalesced upon cooling to low temperature. ${ }^{26}$

X-ray Analyses. The structures of compounds 1, 5, and $\mathbf{7}$ have been determined by X-ray diffraction methods. Views of the three molecules are in Figures 3-5, respectively. The geometry of $\mathbf{5}$ is a typical three-legged piano stool; this is the first reported structure for a

(25) Fettinger, J . C.; Keogh, D. W.; Poli, R. J . Am. Chem. Soc. 1996, 118, 3617-3625.

(26) Grebenik, P. D.; Green, M. L. H.; Izquierdo, A.; Mtetwa, V. S. B.; Prout, K. J . Chem. Soc., Dalton Trans. 1987, 9-19. 


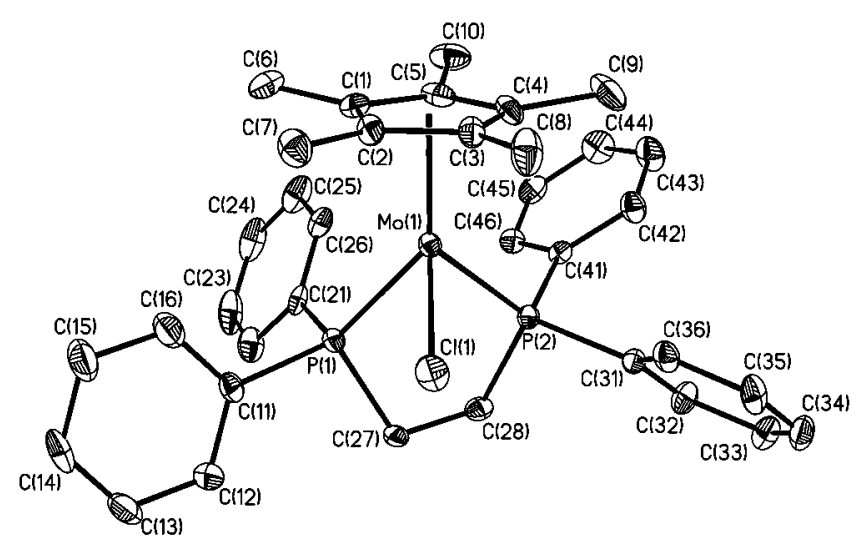

Figure 4. ORTEP diagram of $\mathrm{Cp} * \mathrm{MoCl}(\mathrm{dppe})$ (5).

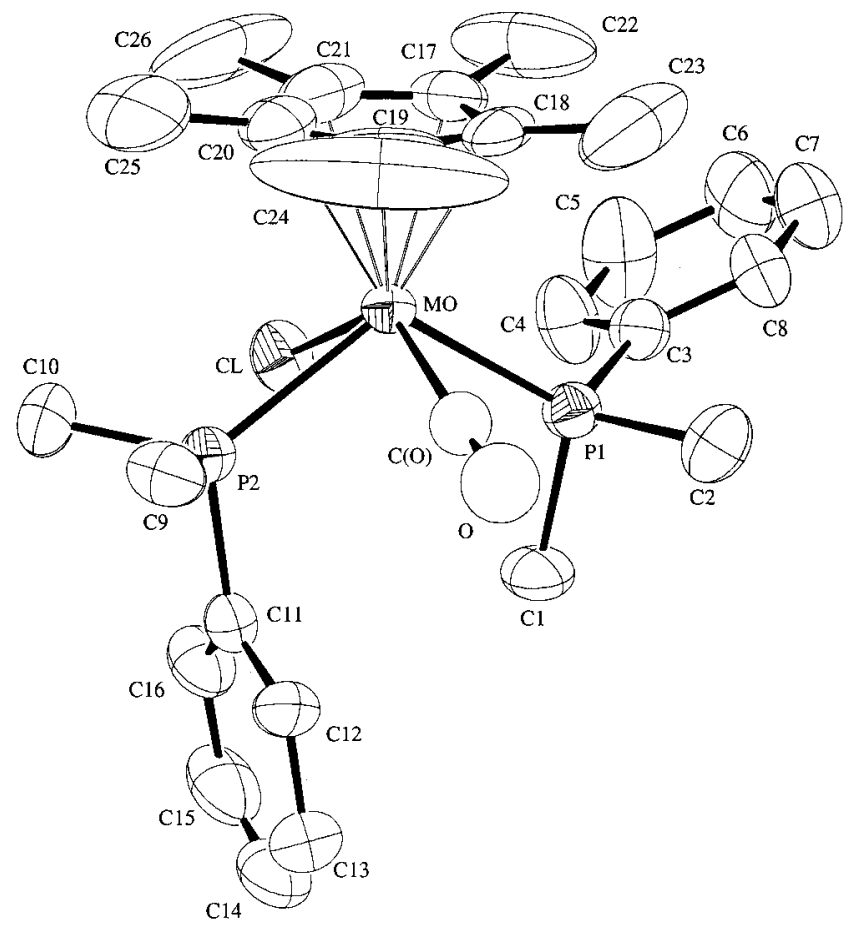

Figure 5. ORTEP diagram of $\mathrm{Cp} * \mathrm{MoCl}(\mathrm{CO})\left(\mathrm{PMe}_{2} \mathrm{Ph}\right)_{2}$ (7).

paramagnetic, 16-electron, organometallic Mo(II) complex. The average $\mathrm{L}-\mathrm{M}-\mathrm{L}$ angle is $85.1(1)^{\circ}$, which compares with the value of $84.7(2)^{\circ}$ for the diamagnetic $\mathrm{CpW}(\mathrm{CO})_{2}\left(\mathrm{POCMe}_{2} \mathrm{CMe} \mathrm{O}_{2} \mathrm{O}\right)$. The average CNT-Mo-L angle (CNT is the Cp ring centroid), i.e. $129(1)^{\circ}$, is significantly larger than for four-legged piano stool compounds, i.e. $115(1)^{\circ}$ for $\mathbf{1}$. One of the other expected structural characteristics is a shorter $\mathrm{Mo}-\mathrm{Cl}$ length (2.416(1) A) compared to 18-electron Mo(II) four-legged species (e.g. 2.585(2) $\AA$ for 1 and 2.526(2) $\AA$ for $\mathrm{CpMoCl-}$ (triphos) (triphos $\left.=\mathrm{Ph}_{2} \mathrm{PCH}_{2} \mathrm{CH}_{2} \mathrm{P}(\mathrm{Ph}) \mathrm{CH}_{2} \mathrm{CH}_{2} \mathrm{PPh}_{2}\right)$ ). ${ }^{27}$ A much less significant difference is observed for the Mo-P lengths, those of 5 (average 2.420(1) $\AA$ ) being only slightly shorter than for 1 (average 2.466(2) $\AA$ ).

Molecular geometries of $\mathbf{1}$ and $\mathbf{7}$ are based on the "four-legged piano stool", which is ubiquitous for compounds of the $\mathrm{CpML}_{4}$ type. ${ }^{28,29}$ The structure of $\mathbf{1}$ is one of the first structures for a fully phosphinesubstituted $\mathrm{CPMoXL}_{3}$ complex (X = any one-electron

(27) Cole, A. A.; Mattamana, S. P.; Poli, R. Polyhedron 1996, 15, 2351-2361.

(28) Kubácek, P.; Hoffmann, R.; Havlas, Z. Organometallics 1982, $1,180-188$

(29) Poli, R. Organometallics 1990, 9, 1892-1900. donor), the only other being that of $\mathrm{CpMoCl}$ (triphos). ${ }^{27}$ The most interesting angular parameters are the angles between the Mo-CNT vector and the other bonds. In the structure of $\mathbf{1}$, the two relative trans donors $\mathrm{Cl}$ and P2 have smaller angles than the other donors $\mathrm{P} 1$ and P3. This follows the established pattern of angular trans influence, ${ }^{29}$ which places the pair of ligands with overall stronger $\sigma$-bonding ability at smaller angles in order to maximize the interaction with the more favorable metal orbitals. ${ }^{30}$ This angular trans influence was also observed in the structure of $\mathrm{CpM} \mathrm{oCl}$ (triphos). ${ }^{27}$ The $\mathrm{Mo}-\mathrm{Cl}$ distance is significantly longer in compound $\mathbf{1}$ (2.58(1) $\AA$ ) compared to CpMoCl(triphos) (2.526(2) $\AA$ ), but is in each case longer than for the Mo(III) complex $\left[\mathrm{CpMoCl}\left(\mathrm{PMe}_{3}\right)_{3}\right]^{+}\left(2.427(9) \AA\right.$ in the $\mathrm{PF}_{6}{ }^{-}$salt ${ }^{22}$ and 2.509(3) $\AA$ in the $\mathrm{BF}_{4}{ }^{-}$salt $\left.^{31}\right)$, as expected. A longer Mo- $\mathrm{Cl}$ bond length is also observed in 7 (2.577(5) $\AA$ ), this being comparable to the same distance in $\mathbf{1}$. Other relevant four-legged piano stool $\mathrm{Mo}(\mathrm{II})$ complexes also show longer $\mathrm{Mo}-\mathrm{Cl}$ distances (e.g. 2.541(5) $\AA$ in $\mathrm{Cp}$ $\mathrm{MoCl}(\mathrm{CO})(\mathrm{dppe})^{32}$ and 2.542(9) $\AA$ in $\mathrm{CpM} \mathrm{OCl}(\mathrm{CO})_{3}{ }^{33}$ ). The Mo-P distances are slightly shorter for $\mathbf{1}$ (average

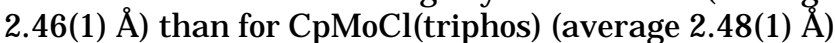
with the length for $7(2.470(2) \AA)$ falling directly in between. A comparison with other literature values (2.388(8) $\AA$ in $\left(\mathrm{C}_{5} \mathrm{H}_{4} \mathrm{Me}\right) \mathrm{Mol}(\mathrm{CO})_{2}\left[\mathrm{P}\left(\mathrm{OM} \mathrm{e}_{3}\right)_{3}\right],{ }^{34} 2.50(1)$ $\AA$ in $\mathrm{CpMol}(\mathrm{CO})_{2}\left(\mathrm{PBu}_{3}\right), 35$ 2.532(6) $\AA$ in $\mathrm{CpMoBr}(\mathrm{CO})_{2^{-}}$ $\left(\mathrm{PPh}_{3}\right),{ }^{36} 2.473(3) \AA$ in $\mathrm{CpMo}\left(\mathrm{COCH}_{3}\right)(\mathrm{CO})_{2}\left(\mathrm{PPh}_{3}\right),{ }^{37}$ and 2.47(3) $\AA$ in $\mathrm{CpMoCl}(\mathrm{dppe})(\mathrm{CO})^{32}$ ) suggests that the Mo-P bonds tend to shorten when more phosphine and fewer CO ligands are present in the coordination sphere (consistent with diminished $\pi$-competition), and a further shortening effect is also due to the presence of chelate rings. A similar effect is also observable for the $\mathrm{M}-\mathrm{C}(\mathrm{O})$ bond length, which is shorter in compound 7 (1.88(2) $\AA$ ) than the average distance in other compounds with less donating ancillary ligands: $1.938(18)$ $\AA$ in $\mathrm{CpMoCl}\left(\right.$ dppe)(CO), 32 1.94(6) $\AA$ in $\mathrm{CpMol}(\mathrm{CO})_{2^{-}}$ $\left(\mathrm{PBu}_{3}\right),{ }^{35} 1.951(13) \AA$ in $\mathrm{CpMo}\left(\mathrm{COCH}_{3}\right)(\mathrm{CO})_{2}\left(\mathrm{PPh}_{3}\right)^{37}$ $2.003(34) \AA$ in $\left(\mathrm{C}_{5} \mathrm{H}_{4} \mathrm{Me}\right) \mathrm{Mol}(\mathrm{CO})_{2}\left[\mathrm{P}\left(\mathrm{OMe}_{3}\right)_{3}\right]{ }^{34}$ and 2.091(14) $\AA$ in $\mathrm{CpMoBr}(\mathrm{CO})_{2}\left(\mathrm{PPh}_{3}\right) .36$

\section{Discussion}

Half-sandwich 18-electron complexes of Mo(II) constitute a very extensive class of compounds. ${ }^{38,39}$ Related complexes with a 16-electron configuration are rare, and most, especially when they contain one or more $\mathrm{CO}$ ligands, have only been observed as transients in chemical reactions. For instance, the $\mathrm{CpMoX}(\mathrm{CO})_{2}(\mathrm{X}$ $=\mathrm{Cl}, \mathrm{CH}_{3}$ ) fragments are obtained by photolytic $\mathrm{CO}$ ejection from $\mathrm{CpMoX}(\mathrm{CO})_{3}$, but the primary photoproduct rapidly reacts with $\mathrm{N}_{2}, \mathrm{C}_{2} \mathrm{H}_{4}, \mathrm{CO}$, and other sub-

(30) Lin, Z.; Hall, M. B. Organometallics 1993, 12, 19-23.

(31) Fettinger, J . C.; Kraatz, H.-B.; Poli, R.; Rheingold, A. L. Acta Crystallogr., Sect. C 1995, C51, 364-367.

(32) Bush, M. A.; Hardy, A. D. U.; Manojlovic-Muir, L.; Sim, G. A. J. Chem. Soc. A 1971, 1003-1009.

(33) Chaiwaise, S.; Fenn, R. H. Acta Crystallogr., Sect. B 1968, B24 525-5219.

(34) Hardy, A. D. U.; Sim, G. A. J . Chem. Soc., Dalton Trans. 1972, 1900-1903.

(35) Fenn, R. H.; Cross, J . H. J . Chem. Soc. A 1971, 3312-3315.

(36) Sim, G. A.; Sime, J. G.; Woodhouse, D. I.; Knox, G. R. Acta Crystallogr., Sect. B 1979, B35, 2403-2406.

(37) Churchill, M. R.; Fennessey, J . P. Inorg. Chem. 1968, 7, 953-

(38) Wilkinson, G.; Stone, F. G. A.; Abel, E. W. Comprehensive Organometallic Chemistry; Pergamon: Oxford, U.K., 1982.

(39) Wilkinson, G.; Stone, F. G. A.; Abel, E. W. Comprehensive Organometallic Chemistry II; Pergamon: Oxford, U.K., 1995. 


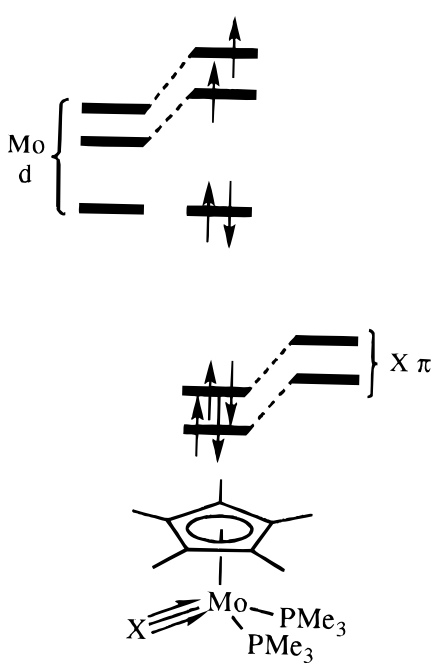

(a)
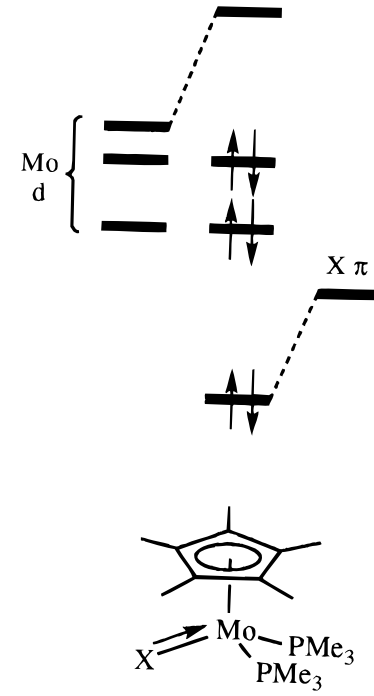

(b)
Figure 6. Qualitative $\mathrm{MO}$ diagram for the $\mathrm{M}-\mathrm{X} \pi$ interaction: (a) interation with the double-sided $\mathrm{Cl}$; (b) interaction with the single-sided $\mathrm{PR}_{2}$.

strates to afford saturated adducts. ${ }^{40-42}$ Rare examples of stable 16-electron complexes are based on the general formula (Ring)MoXL $L_{2}$, where Ring is Cp or a substituted derivative, $L$ is $C O$ or phosphine, and $X$ is an efficient $\pi$-donor group such as a phosphido or arsenido ligand. ${ }^{20,43-45}$ Consequently, all these complexes are effectively electronically saturated and are diamagnetic. Nevertheless, some of them readily add ligands to form 18-electron adducts. The complexes $\mathbf{2}-\mathbf{5}$ reported in this contribution are the first organometallics of Mo(II) to be stable as spin triplet ground states for a 16electron configuration.

It is interesting to compare the spin triplet compound $\mathrm{Cp} * \mathrm{MoCl}\left(\mathrm{PMe}_{3}\right)_{2}$ with the previouly reported spin singlet compounds $\mathrm{Cp} * \mathrm{Mo}\left(\mathrm{PR}_{2}\right)\left(\mathrm{PMe}_{3}\right)_{2}(\mathrm{R}=\mathrm{Ph}$, cyclohexyl). ${ }^{20}$ This spin state difference can be rationalized on the basis of differences in frontier orbital gaps and pairing energies. Considering these complexes in a similar light as low-valent organometallics with covalent bonding, the open-shell configuration can gain stability through $\pi$-bonding. Chlorine is a double-sided $\pi$-donor and is therefore capable of interacting with and raising the energy of two of the frontier metal orbitals (see Figure 6a). Consequently, the gap between the two highest orbitals is small. Conversely, the phosphide is a single-sided $\pi$-donor and is only able to raise the energy of one metal orbital (Figure 6b), resulting in a larger energy gap between the two highest metal-based orbitals. From the point of view of pairing energies, it has to be recognized that the chlorine atom has a higher electronegativity than the $\mathrm{PR}_{2}$ function; thus, a greater effective positive charge on the metal center is expected,

(40) Hooker, R. H.; Mahmoud, K. A.; Rest, A. J . J . Chem. Soc., Dalton Trans. 1990, 1231-1241.

(41) Hill, R. H.; Becalska, A.; Chiem, N. Orgtanometallics 1991, 10, 2104-2109.

(42) Virrels, I. G.; George, M. W.; J ohnson, F. P. A.; Turner, J . J .; Westwell, J . R. Organometallics 1995, 14, 5203-5208.

(43) Luksza, M.; Kimmer, S.; Malisch, W. Angew. Chem., Int. Ed. Engl. 1983, 22, 416-417.

(44) Gross, E.; J örg, K.; Fiederling, K.; Göttlein, A.; Malisch, W.; Boese, R. Angew. Chem., Int. Ed. Engl. 1984, 23, 738-739.

(45) Malisch, W.; Pfister, H. Organometallics 1995, 14, 4443-4445. causing contraction of the metal-based orbitals and therefore a greater pairing energy. The spin state difference between the 6-coordinate, 14-electron derivatives trans-TiX ${ }_{2}(\text { dmpe })_{2}(\mathrm{~S}=1$ for $\mathrm{X}=\mathrm{Cl}$; $\mathrm{S}=0$ for $\mathrm{X}$ $\left.=\mathrm{CH}_{3}\right)^{46}$ has analogously been attributed to smaller pairing energies in the dimethyl compound because of the lower electronegativity of $\mathrm{CH}_{3}$ relative to $\mathrm{Cl} .{ }^{47}$ These Cp*MoX $\left(\mathrm{PMe}_{3}\right)_{2}$ systems are isolobal with the known trans-octahedral $\mathrm{MoCl}_{2}\left(\mathrm{PMe}_{3}\right)_{4},{ }^{48}$ which shows the expected triplet ground state for the pseudo- $t_{2 g}{ }^{4}$ configuration.

It is important to realize that, although each $\mathrm{Mo}-\mathrm{Cl}$ $\pi$ interaction is rendered less effective by the antibonding electron with respect to the single $\mathrm{Mo}-\mathrm{PR}_{2} \pi$-interaction, the overall $\mathrm{Mo}-\mathrm{Cl} \pi$-donation is still worth 2 electrons and contributes to the energetic stabilization of the molecule. This is most clearly indicated by the significant contraction of the $\mathrm{Mo}-\mathrm{Cl}$ bond on going from the 18-electron $\mathbf{1}$ and $\mathbf{7}$ to the 16-electron $\mathbf{5}$ (see Results). For this reason, we represented the $\mathrm{Mo}-\mathrm{Cl} \pi$-interactions as two single-pointed arrows in Figure 6a.

The 16-electron complexes (Ring) MoClL 2 react with 2-electron-donor ligands, i.e. $\mathrm{CO}$ and $\mathrm{H}_{2}$, to afford stable saturated 18-electron complexes. It has also been shown earlier that 3 reacts with $\mathrm{N}_{2}$ to afford an 18-electron dinitrogen adduct. ${ }^{18}$ These reactions involve a spin state change from $S=1$ to $S=0$. Evidently, the energetic gain associated with the formation of the new bonds more than compensates for the cost of pairing the electrons and for the loss of $\mathrm{Mo}-\mathrm{Cl} \pi$-stabilization. It is expected that the strength of the new $M-L$ bonds will affect the overall enthal pic picture. Indeed, the stronger $\mathrm{Mo}-\mathrm{CO}$ bond results in a quantitative carbonylation reaction, whereas $\mathrm{N}_{2}$ leads to an equilibrium mixture of starting material and dinitrogen adduct ${ }^{18}$ and weaker donor molecules such as noble gases, hydrocarbons, acetone, and THF do not react. The energetics of these adduct formations have been investigated theoretically and are reported in a separate contribution, which also addresses the effect of this spin state change on the reaction kinetics. ${ }^{49}$

A final point of consideration is related to the different behavior of Mo and W. Baker et al. have reported that the reduction of $\mathrm{Cp}^{*} \mathrm{WCl}_{4}$ with 3 equiv of $\mathrm{Na}$ in the presence of $\mathrm{PMe}_{3}$ (a procedure identical with that in eq 1 for the synthesis of 3) leads to the compound Cp*W$(\mathrm{H})(\mathrm{Cl})\left(\mathrm{PMe}_{3}\right)\left(\eta^{2}-\mathrm{CH}_{2} \mathrm{PMe}_{2}\right)$, featuring a metallated $\mathrm{PMe}_{3}$ ligand. 20 The formation of this product probably involves a $\mathrm{C}-\mathrm{H}$ oxidative addition process on a 16-electron $\mathrm{Cp} * \mathrm{WCl}\left(\mathrm{PMe}_{3}\right)_{2}$ intermediate, i.e. identical with the stable Mo product 3 (see Scheme 1). On the other hand, compound $\mathbf{3}$ fails to afford the corresponding product of $\mathrm{PMe}_{3}$ metalation. Rather, upon warming, it decomposes, probably via a radical mechanism, to produce $\mathrm{Cp}^{*} \mathrm{MoCl}_{2}\left(\mathrm{PMe}_{3}\right)_{2}$ and $\mathrm{Cp} * \mathrm{MoH}\left(\mathrm{PMe}_{3}\right)_{3}$ as the only identified products by NMR and EPR.

This different behavior may be attributed either to a greater kinetic barrier to the $\mathrm{C}-\mathrm{H}$ oxidative addition process in the Mo case or to the greater thermodynamic

(46) Morris, R. J .; Girolami, G. S. Inorg. Chem. 1990, 29, 41674169.

(47) Simpson, C. Q., II; Hall, M. B.; Guest, M. F. J . Am. Chem. Soc. 1991, 113, 2898-2903.

(48) Carmona, E.; Marín, J . M.; Poveda, M. L.; Atwood, J . L.; Rogers, R. D. Polyhedron 1983, 2, 185-193.

(49) Keogh, D. W.; Poli, R. J. Am. Chem. Soc., submitted for publication. 


\section{Scheme 1}
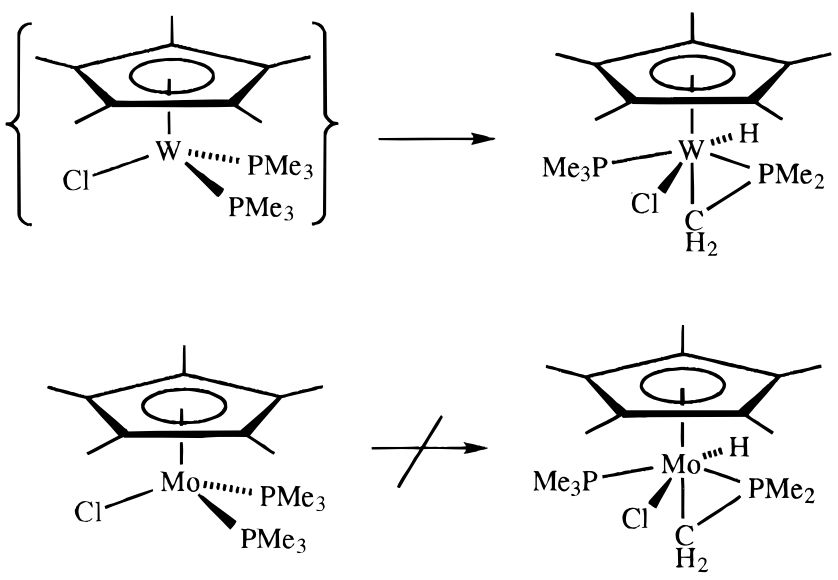

stability of the 16-electron system with respect to the product of $\mathrm{PMe}_{3}$ metalation in the case of Mo. The effect of the spin state change on the thermodynamic picture for an oxidative-addition process should be opposite to that of a ligand addition (see Introduction), because the ideal removal of the $X$ and $Y$ radicals from an 18electron $L_{n} M(X)(Y)$ complex leaves the metal with two unpaired electrons (triplet state). Siegbahn has explained in this manner the computational results of a lower thermodynamic gain for the oxidative addition of $\mathrm{CH}_{4}$ to $\mathrm{CpRh}(\mathrm{CO})$ with respect to $\mathrm{Cpl}$ (CO), since the spin triplet starting complex is less stable by $5.9 \mathrm{kcal} /$ mol for $\mathrm{Rh}$ and more stable by $0.3 \mathrm{kcal} / \mathrm{mol}$ for $1 \mathrm{r} .{ }^{5}$ Thus, while a triplet configuration for a 16-electron $M L_{n}$ complex would provide thermodynamic stabilization with respect to the formation of a diamagnetic 18electron $L_{n} M\left(L^{\prime}\right)$ adduct, it would not provide any stabilization with respect to the formation of a diamagnetic 18-electron $L_{n} M(X)(Y)$ oxidative-addition product. The spin state of the hypothetical 16-el ectron $\mathrm{Cp} * \mathrm{WCl}$ $\left(\mathrm{PMe}_{3}\right)_{2}$, let alone the magnitude of the singl et-triplet gap, is not known; therefore, the relevance of the spin state change to the different behavior of Mo and $\mathrm{W}$ in Scheme 1 remains undetermined. However, a more favored oxidative-addition process for the $\mathrm{W}$ system could also derive from an increased strength of the $\mathrm{W}-\mathrm{H}$ and $\mathrm{W}-\mathrm{CH}_{2}$ bonds with respect to the same bonds for Mo. It is an experimental fact that oxidative-addition processes are more favored for $5 d$ relative to $4 d$ systems, even when there is no spin state change involved in either process (e.g. addition to square-planar $\mathrm{Rh}(\mathrm{I})$ and Ir(I) Vaska-type complexes).

Acknowledgment. We are grateful to the National Science Foundation (Grant No. CHE-9508521) for support of this work.

Supporting Information Available: For compounds 1, 5, and 7, tables of crystal data and refinement parameters, fractional atomic coordinates, bond distances and angles, anisotropic thermal parameters, and $\mathrm{H}$ atom coordinates (27 pages). Ordering information is given on any current masthead page. 